\title{
LOS ESCRITORES Y EL QUIJOTE
}

\author{
Nicolás Salerno y Pablo Tenekedjian
}

INTRODUCCIÓN

$\mathrm{E}_{1 \text { presente documento se propone poner al alcance del lector una }}$ variedad de textos en torno a la obra capital de Miguel de Cervantes, escritos por algunas de las figuras centrales de la literatura y el pensamiento occidental (véase listado de autores y obras escogidas en pp. 535-536). Los textos, agrupados en ocho secciones temáticas, aparecen precedidos en cada sección por un diálogo representativo del Quijote y, a continuación, por una breve nota introductoria.

No pretendemos ser exhaustivos — no podríamos-, ni en la selección ni en las notas. El aporte, en este caso, es apenas un hilo que engarza los diferentes textos (fragmentos de cuentos, poemas, ensayos, novelas, diarios, críticas literarias, cartas, conferencias, etc.). Hemos preferido, antes

Nicolás Salerno Fernández. Licenciado en Lengua y Literatura Hispánica. Candidato a Magíster en Literatura Chilena e Hispanoamericana, Universidad de Chile. Ayudante becario de Magíster en Literatura, Universidad de Chile. Entre sus publicaciones se cuentan "Neruda: Sus críticos y sus biógrafos", Estudios Públicos, 94 (2004).

Pablo Tenekedjian Payer. Licenciado en Lengua y Literatura Hispánica. Candidato a Magíster en Literatura Española, Universidad de Chile. Profesor de Literatura Española, Universidad Diego Portales. Autor de ensayos de crítica literaria y poesía.

Estudios Públicos, 100 (primavera 2005). 
que atenernos a la época o la nacionalidad, que la linealidad esté dada —un poco arbitrariamente, pero esperamos, poéticamente - por la interconexión de meditaciones, reformulaciones, interpretaciones y recreaciones en la cronología del texto cervantino. Los diálogos, quizá la técnica más valorada en Cervantes, sirven a este fin. Así, un fragmento del Quijote $^{1}$ da lugar al arte próximo, al pensamiento próximo, con lo que se viene a cumplir una de las máximas de Malraux: "Toda narración está más cerca de las narraciones anteriores que del mundo que nos rodea, y cuando las obras más divergentes se reúnen en el museo o en la biblioteca, no lo hacen por su relación con la realidad, sino por sus relaciones mutuas" ${ }^{2}$. Una pregunta cervantina estaría en relación con el perspectivismo o la subjetividad de esa realidad. En nuestras notas veremos esas relaciones, apuntaremos otras y mostraremos algunas líneas usuales de la influencia cervantina en autores de diversas épocas. No se trata de una antología propiamente tal, ni mucho menos, claro está, de un estudio crítico, sino sólo de una indicación adrede e impuesta por la materia tratada. El lector comprenderá la infinitud de sus multiplicaciones y el hecho de no poder dar cuenta cabalmente de tantas implicancias. La figura del crítico desaparece para ceder la voz al texto original y a sus consecuencias; se hace un mero jugador de rompecabezas, un arquitecto que casi delega el monumento a la imaginación lectora.

Nos interesa, en definitiva, el rescate de algunos pasajes del Quijote, significativos, simbólicos, que han dado lugar al imaginario artístico, a los grandes hombres de letras, encantadores, creadores y criadores, que en su dimensión no han dejado de volver sobre la novela máxima de la literatura universal. Nos interesan las palabras de tales hombres, no las nuestras.

${ }^{1}$ Los fragmentos de Don Quijote que aquí se reproducen están tomados de la edición IV Centenario de la Real Academia Española y la Asociación de Academia de la Lengua española, 2004.

2 André Malraux, El hombre precario y la literatura (Buenos Aires: Sur, 1977). 


\section{IDENTIDAD: "YO SÉ QUIÉN SOY"}

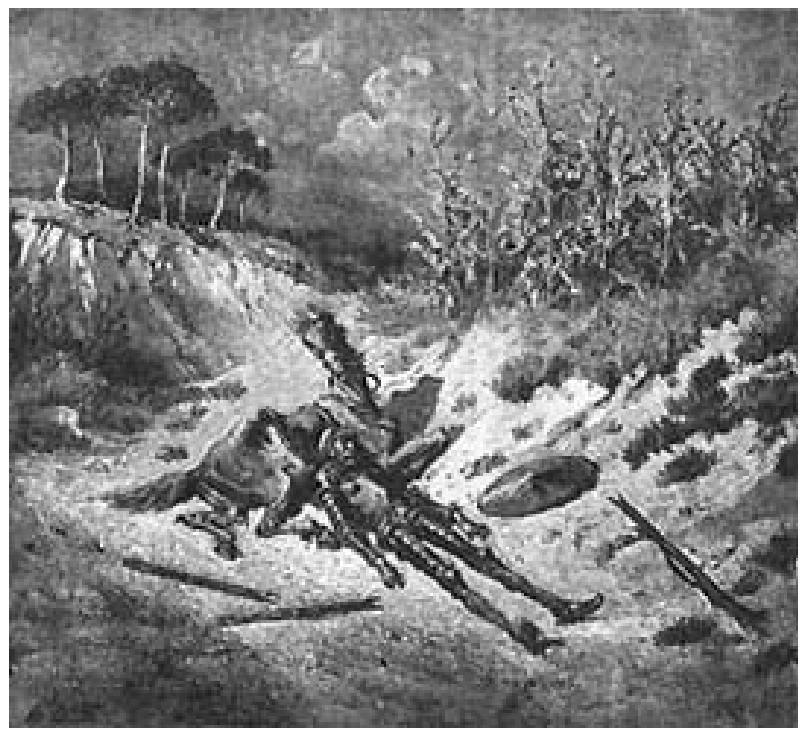

G. Doré

"-Señor Quijana —que así se debía de llamar cuando él tenía juicio y no había pasado de hidalgo sosegado a caballero andante-, ¿quién ha puesto a vuestra merced desta suerte?

Pero él seguía con su romance a cuanto le preguntaba. Viendo esto el buen hombre, lo mejor que pudo le quitó el peto y espaldar, para ver si tenía alguna herida; pero no vio sangre ni señal alguna. Procuró levantarle del suelo, y no con poco trabajo le subió sobre su jumento, por parecerle caballería más sosegada. Recogió las armas, hasta las astillas de la lanza, y liólas sobre Rocinante, al cual tomó de la rienda y del cabestro al asno, y se encaminó hacia su pueblo bien pensativo de oír los disparates que don Quijote decía; y no menos iba don Quijote, que, de puro molido y quebrantado, no se podía tener sobre el borrico, y de cuando en cuando daba unos suspiros que los ponía en el cielo, de modo que de nuevo obligó a que el labrador le preguntase, le dijese qué mal sentía. Y no parece sino que el diablo le traía a la memoria los cuentos acomodados a sus sucesos; porque en aquel punto, olvidándose de Valdovinos, se 
acordó del moro Abindarráez, cuando el alcaide de Antequera, Rodrigo de Narváez, le prendió y llevó cautivo a su alcaldía; de suerte que, cuando el labrador le volvió a preguntar que cómo estaba y qué sentía, le respondió las mismas palabras y razones que el cautivo Abencerraje respondía a Rodrigo de Narváez, del mesmo modo que él había leído la historia en La Diana de Jorge de Montemayor, donde se escribe; aprovechándose della tan de propósito, que el labrador se iba dando al diablo de oír tanta máquina de necedades; por donde conoció que su vecino estaba loco; y dábase priesa a llegar al pueblo por excusar el enfado que don Quijote le causaba con su larga arenga. Al cabo de la cual dijo:

- Sepa vuestra merced, señor don Rodrigo de Narváez, que esta hermosa Jarifa que he dicho es ahora la linda Dulcinea del Toboso, por quien yo he hecho, hago y haré los más famosos hechos de caballerías que se han visto, vean ni verán en el mundo.

A esto respondió el labrador:

- Mire vuestra merced, señor, ipecador de mí!, que yo no soy don Rodrigo de Narváez ni el marqués de Mantua, sino Pedro Alonso, su vecino; ni vuestra merced es Valdovinos, ni Abindarráez, sino el honrado hidalgo del señor Quijana.

—Yo sé quién soy — respondió don Quijote—, y sé que puedo ser no sólo los que he dicho, sino todos los Doce Pares de Francia y aun todos los nueve de la Fama, pues a todas las hazañas que ellos todos juntos y cada uno por sí hicieron, se aventajarán las mías."

(Primera Parte, Cap. V, pp. 56-58.)

$$
* * *
$$

Para Ortega y el 98', el Quijote pudo convertirse en centro de tensiones sociales, símbolo de huida ante una realidad adversa, solución imaginaria a una lucha social, más específica, de clase. Numerosos escritores toman a un don Quijote en su circunstancia, en la figura del Hidalgo cayendo de su pirámide, en su cornisa y abismo, al desplomarse su estima social y privilegios ante los fracasos de las realizaciones colectivas españolas. Desde este punto de vista la afirmación de un "ser otro", una decisión a la que es arrastrado el hombre, se hizo icono en la creación y remedo de muchos.

La otredad, el doble, el desdoblamiento, la huida, son temas repetidos para escritores sociales que ponen en vilo el problema de la identidad. El juego de la imaginación como escape al ser real y el hacer real del hombre 
en el mundo, son otros de los intermitentes dramas del ser humano; porque don Quijote se desdobla, sí, pero el hacer de los otros personajes porque vuelva al mundo de ellos hasta señalarse "loco fui, cuerdo soy" (sus aparentes vueltas, su regreso final para morir), siempre va a tener relación con la actuación moral del hombre. Es el Bueno, cuando regresa; ocupa su rol cuando regresa: desde ahí el fragmento de "Clarín", la visión de Faulkner, el ejemplo de Conrad para su crítica de arte.

Así como el afirmarse otro puede ser evasión, y el ejemplo moral que sacó la Ilustración de esto es evidentemente negativo, otros han visto -el Romanticismo casi siempre - el aspecto positivo de la decisión, de la voluntad sobre el determinismo, y antes que concluir con pesimismo, volvieron la vista a la fortaleza del ideal y a cómo esta seguridad del "Yo sé quién soy" transforma al hombre en una mejor persona, éticamente hablando; porque don Quijote es también un altruista y casi todo escritor (don Quijote pudo decidir entre escribir o vivir sus ideales) que no haga de su arte una herramienta para mejorar el mundo, para varios peca de egoísmo. ¿Quién está loco? Desde ahí, Turgueniev; desde ahí, Papini.

\section{La fantasía de un delegado de Hacienda ${ }^{3}$}

“Clarín” (Leopoldo Alas) (1852-1901)

Don Sinibaldo de Rentería había llegado por sus pasos contados, y sin deber los ascensos a intrigas ni aldabas, a ocupar el puesto de jefe en las oficinas de Hacienda en una provincia de primera clase. No había mejor empleado en el ramo, y nada tenía que ver con su aptitud para el cargo la acalorada fantasía que Dios le había concedido. Dividía la vida en dos partes: de un lado los expedientes con toda su horrible realidad, apremios y embargos inclusive; de otro lado la loca de la casa, que hacía vivir a don Sinibaldo en perpetua novela interior, en continua hipótesis histórica. Porque él llamaba así a su manía invencible.

"En la hipótesis —empezaba a pensar - de que yo fuera esto y lo otro, y me sucediera tal cosa..."

Y seguía imaginando aventuras, incidentes, episodios, lugares, diálogos, actitudes; en fin, creando un mundo en que se enfrascaba, y a poco, ya tomaba por el único positivo. Esta transformación de la hipótesis en soñada realidad era involuntaria. En esto se parecía el delegado de Hacien-

${ }^{3}$ Tomado del cuento La fantasía de un delegado de Hacienda (Oviedo, España: Nobel, 1999). 
da a no pocos sabios que empiezan inventando también modestamente una hipótesis, y al cabo juran que es la verdad pura y que "no le mana, canalla infame...", con todo lo demás que Don Quijote aseguraba de Dulcinea o de la modesta Madasima. De su embelesamiento, de su universo fantástico, solía sacarle a don Sinibaldo algún encuentro brusco con... una esquina, o un pisotón de un mozo de cordel; y el soñador volvía al triste mundo de los demás, exclamando:

—Animal, ¡mire usted por dónde anda!

Sin ver que, por andar él por los espacios imaginarios, era por lo que le pisaba un humilde gallego. De esto hay mucho en la vida, y también en el Don Quijote, al que la vida tanto se parece.

\section{Un vagabundo feliz ${ }^{4}$ \\ Joseph Conrad (1857-1924)}

Todos los conversos son interesantes. Los más de nosotros, si me perdonan el que traicione este secreto universal, nos hemos descubierto en un momento u otro cierta disposición a perdernos por el mal camino. ¿Y qué hemos hecho, en nuestro orgullo y cobardía? Echando miradas furtivas y aguardando el momento oscuro hemos enterrado nuestro descubrimiento discretamente, para seguir luego en la misma dirección de antes y esa senda tan transitada, que no tuvimos el valor de dejar y que ahora, más claramente que nunca, advertimos que no es sino el largo camino que lleva a la tumba. El converso, el hombre capaz de gracia (hablo en sentido seglar) no es discreto; su orgullo es de otra clase. Abandona rápidamente la senda - el toque de gracia es casi siempre súbito- y orientándose en una nueva dirección incluso puede hacerse la ilusión de haberle vuelto la espalda a la misma Parca.

Conversos ha habido que, por su exquisita indiscreción, han ganado inmortalidad cierta. El ejemplo más ilustre, esa flor de la Caballería, don Quijote de la Mancha, sigue siendo para todo el mundo el único hidalgo genuino y eterno. Como saben, el delicioso Caballero de España se convirtió a una fe imperativa en una misión tierna y sublime que lo alejó del hacer y de las costumbres propias del pequeño hidalgo provinciano. Luego sería apaleado, y con el tiempo hasta encerrado en jaula de madera por el Barbero y el Cura, apropiados ministros de un orden social justamente soliviantado. No sé si a alguien se le habrá ocurrido encerrar a Mr. Luffmann en una jaula

\footnotetext{
Ediciones B, 1988).
} 
de madera. Y no lo traigo a colación porque le desee daño alguno. Al contrario, me considero una persona humanitaria. Que lo tome, pues, como máxima alabanza, aunque debo decir que merece sobradamente esa clase de atención.

Por otra parte, no me gustaría que se sintiera excesivamente halagado por el orgullo de esa asociación tan exaltada. La grave sabiduría, la admirable amenidad, la serena gracia del patrón-santo secular de todos los mortales conversos a nobles visiones no son suyas. Mr. Luffmann carece de misión. No es un Caballero sublimemente Errante. Pero es un excelente Vagabundo. Tiene mucho mérito. Ese peripatético guía, filósofo y amigo de todas las naciones, Mr. Roosevelt, lo excomunicaría inmediatamente con una gran vara. La verdad es que el ex-autócrata de todos los Estados no gusta de rebeldes contra el hosco orden de nuestro Universo. Aprovechadlo lo mejor que podáis o morid, grita. Sano sucesor en la línea del Barbero y del Cura, y sagaz heredero político del incomparable Sancho Panza (otro gran Gobernador) este distinguido littérateur no guarda piedad alguna para con los soñadores. Y nuestro autor (podrán apreciarlo en sus libros) atesora algunos sueños de no poca calidad.

\section{"Entrevista a William Faulkner"5}

William Faulkner (1897-1962)

- Los críticos también sugieren que sus personajes nunca eligen conscientemente entre el bien y el mal.

- A la vida no le interesa el bien y el mal. Don Quijote elegía constantemente entre el bien y el mal, pero elegía en su estado de sueño. Estaba loco. Entraba en la realidad sólo cuando estaba tan ocupado bregando con la gente que no tenía tiempo para distinguir entre el bien y el mal. Puesto que los seres humanos sólo existen en la vida, tienen que dedicar su tiempo simplemente a estar vivos. La vida es movimiento y el movimiento tiene que ver con lo que hace moverse al hombre, que es la ambición, el poder, el placer. El tiempo que un hombre puede dedicarle a la moralidad, tiene que quitárselo forzosamente al movimiento del que él mismo es parte. Está obligado a elegir entre el bien y el mal tarde o temprano, porque la conciencia moral se lo exige a fin de que pueda vivir consigo mismo el día de mañana. Su conciencia moral es la maldición que tiene que aceptar de los dioses para obtener de éstos el derecho a soñar.

${ }^{5}$ Fragmento de "Entrevista a Faulkner", tomado de la antología preparada por Ana Ayuso, El oficio de escritor. Entrevistas (México: Biblioteca ERA, 1986). 


\section{Hamlet y Don Quijote: dos visiones de la vida ${ }^{6}$}

Iván Turgueniev (1818-1883)

¿Qué representa Don Quijote?

Ante todo, la fe; la fe en algo eterno, inmutable; en una palabra: en la verdad, en la verdad que se encuentra fuera del individuo, pero que es posible alcanzar; que exige un servicio y sacrificios, pero a la que se accede gracias a la constancia en ese servicio y a la fuerza de esos sacrificios.

Don Quijote consideraría vergonzoso vivir para sí mismo, preocuparse de su persona. Él vive (si se puede expresar así) fuera de sí mismo, para los demás, para sus hermanos, para extirpar el mal, para enfrentarse a las fuerzas enemigas de la humanidad: a los magos y a los gigantes, es decir, a los opresores. En él no hay rastro de egoísmo, no se preocupa de su persona, se sacrifica por entero - japrecien el valor de esa palabra!_-, cree, cree firmemente y marcha sin volver la vista atrás. Su corazón es humilde; su alma, grande y audaz.

$\mathrm{Su}$ conmovedora devoción no restringe su libertad. Ajeno a la soberbia, no alberga dudas sobre sí mismo, sobre su vocación, ni siquiera sobre sus fuerzas físicas. Sabe pocas cosas, pero no necesita saber mucho. Sabe cuál es su misión, para qué vive en el mundo, y ése es el conocimiento más importante. La fortaleza de su estructura moral (fíjense en que este loco caballero andante es la criatura más profundamente moral que existe en el mundo) dota de una grandeza, de una fuerza especial a todos sus juicios y palabras, a toda su figura, a pesar de las situaciones cómicas y humillantes en las que cae constantemente... Don Quijote es un entusiasta, un servidor de una idea que le ilumina con su fulgor.

\section{Don Quijote ${ }^{7}$}

Giovanni Papini (1881-1956)

Don Quijote no está loco. La disposición no es loca ni involuntaria. Pertenece al tipo común de los Feos y los Ameltis. Él se pretende loco. Su locura es simulada, construida. Crea un estilo de extravagancia para salir de los hábitos muertos de Argamasilla. Inventa las dificultades sin los miedos porque conoce que él es el motor, siempre presente a sí mismo, preparado para dar el freno y girar de lado. Por esto no es trágico y desesperado. Toda su aventura es una diversión preparada. Él puede estar sereno porque sólo él sabe el fondo del juego que es capaz, afirma el juego en el alma para la angustia verdadera. Don Quijote no es serio.

${ }^{6}$ Fragmento del ensayo "Hamlet y Don Quijote: Dos visiones de la vida", tomado de Páginas autobiográficas (Barcelona: Alba Editorial, 2000).

${ }^{7}$ Fragmento de "Don Chisciotte", tomado de Testimonianze (Milán: Facchi, 1918). Traducción al castellano de Alfonsina Salerno. 


\section{EL AUTOR Y EL PERSONAJE}

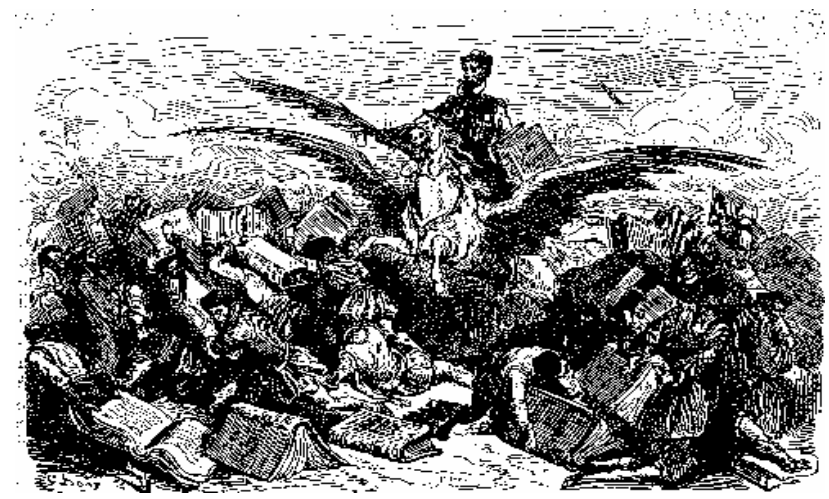

G. Doré

“-Éste es —siguió el barbero- El Cancionero, de López Maldonado.

- También el autor de ese libro — - replicó el cura- es grande amigo mío, y sus versos en su boca admiran a quien los oye, y tal es la suavidad de la voz con que los canta, que encanta; algo largo es en las églogas, pero nunca lo bueno fue mucho; guárdese con los escogidos. Pero ¿qué libro es ése que está junto a él?

—La Galatea, de Miguel de Cervantes —dijo el barbero.

- Muchos años ha que es grande amigo mío ese Cervantes, y sé que es más versado en desdichas que en versos. Su libro tiene algo de buena invención, propone algo, y no concluye nada; es menester esperar la segunda parte, que promete; quizá con la enmienda alcanzará del todo la misericordia que ahora se le niega; y entre tanto que esto se ve, tenedle recluso en vuestra posada, señor compadre."

(Primera Parte, Cap. VI, p. 68.)

$$
* * *
$$

La inclusión del nombre del autor como personaje de ficción —los juegos de niveles en la ficcionalización de la novela - es uno de los elemen- 
tos que suelen citarse como propios y fundadores de la novela moderna. Las posibilidades del juego ficción-realidad son evidentes. Por otra parte, la parodia sobre la técnica de los libros de caballerías, de un autor historiador y el consiguiente engaste sobre los puntos de la verosimilitud de lo narrado, así como la ambigüedad, el cambio, las interferencias en la narración, despertaron la conciencia e hicieron estallar la imaginación sobre el problema fundamental al que se enfrenta, según Vargas Llosa, todo novelista: “¿quién cuenta la historia?”.

Cuando el siglo XVIII elevó la figura de Cervantes, hizo apología y valoró su nombre más que su propia obra, nació lo que se conoce como Cervantismo; la contraparte, el Quijotismo, comenzó bastante después a desligar la figura del autor y a reconocer la obra por sí misma y a ver a Cervantes como un genio inconsciente. Del Quijotismo podemos destacar al menos dos vertientes: la del personaje, que ve a don Quijote como quien se crea a sí mismo y se centra en su figura (Unamuno), y la de la obra, que no pierde de vista la pertenencia del personaje a un todo creado (Ortega y Gasset, por ejemplo).

Desde estas posturas, varias han sido las creaciones que siguieron comentando el problema.

\section{Los Sanchos de Criptana ${ }^{8}$}

“Azorín” (José Martínez Ruiz) (1873-1967)

—Señor Azorín — me dice—, yo he compuesto un himno a Cervantes para que sea cantado en el centenario...

-Perfectamente, don Bernardo - contesto yo.

— ¿Quiere usted oírlo, señor Azorín — torna él a decirme.

- Con mucho gusto, don Bernardo - vuelvo yo a contestarle. $\mathrm{Y}$ don Bernardo tose un poco, vuelve a toser y comienza a cantar en voz baja, mientras el coche da unos zarandeos terribles:

${ }^{8}$ Fragmento de "Los Sanchos de Criptana", tomado de La ruta de Don Quijote (Madrid: Ediciones Cátedra S.A., 1999). 
Gloria, gloria, cantad a Cervantes, creador del Quijote inmortal...

La luz clara del día ilumina la dilatada y llana campaña; se columbra el horizonte limpio, sin árboles; una pincelada de azul intenso cierra la lejanía.

La galera camina y camina por el angosto caminejo. ¿Cuánto tiempo ha pasado desde nuestra salida? ¿Cuánto tiempo ha transcurrido aún? ¿Dos, tres, cuatro, cinco horas? Yo no lo sé; la idea de tiempo, en mis andanzas por la Mancha, ha desaparecido de mi cerebro.

- Señor Azorín — me dice don León—, ya vamos a llegar; falta una legua.

Y pasa un breve minuto en silencio. Don Bernardo inclina la cabeza hacia mí y susurra en voz queda:

-Este himno lo he compuesto para que se cante en el centenario del Quijote. ¿Ha reparado usted en la letra? Señor Azorín, ¿no podría usted decirme de él dos palabras?

— ¡Hombre, don Bernardo! — exclamo yo- . No necesita usted hacerme esta recomendación; para mí es un deber de patriotismo el hablar de ese himno.

- Muy bien, muy bien, señor Azorín — contesta don Bernardo satisfecho.

¿Pasa media hora, una hora, dos horas, tres horas? El coche da tumbos y retumbos; la llanura es la misma llanura gris, amarillenta, rojiza.

- Ya vamos a llegar — repite don León.

- Ahora, cuando lleguemos — añade don Bernardo_-, tocaremos el himno en el armónium de la ermita...

-Ya vamos a llegar - torna a repetir don León.

Y transcurre una hora, acaso hora y media, tal vez dos horas. Yo os torno a asegurar que ya no tengo, ante estos llanos, ni la más remota idea del tiempo. Pero, al fin, allá sobre un montículo pelado, se divisa una casa. Esto es el Cristo de Villajos. Ya nos acercamos. Ya echamos pie a tierra. Ya damos pataditas en tierra para desentumecernos. Ya don Bernardo - este hombre terrible y amable — nos lleva a todos a la ermita, abre el armónium, arranca de él unos arpegios plañideros y comienza a gritar:

Gloria, gloria, cantad a Cervantes creador del Quijote inmortal. 


\section{Quién 9}

Carlos Cañeque (1957)

Con inocencia temeraria, Gilabert pregunta a todos desde su rocín:

-Por favor, ¿saben ustedes quién es el autor de esta novela?

Tras un silencio tenso, Unamuno se acerca a nosotros y se detiene señalando a Gilabert. Luego se arrodilla y, sensiblemente emocionado, besa las pezuñas del rocín.

— ¡Maestro don Quijote, es usted el único autor, el único, el único!

Gilabert se intranquiliza y muestra su desconcierto. Unas risotadas procedentes de las hamacas nos llegan a todos haciéndose evidentes a pesar del sonido del agua. Hasta mi jumento, que mira ahora a Gilabert, parece ahora sorprendido frente a esta súbita alteración de identidades. Despacio, con el silencio de todos, Gilabert desciende de su rocín. Un líquido oscuro comienza a brotar de la punta de su lanza. Se mira las manos, se las huele, se las vuelve a mirar. Unamuno se apresura a levantarse del suelo y a llegar hasta él para darle un abrazo. Luego besa el suelo y llora y palpa con las manos el simbólico líquido negro.

— ¡Lo veis! — grita mirando a todos con ojos desorbitados y felices-. iEstá fluyendo tinta de su lanza, está fluyendo tinta, os lo dije, os lo dije! ¡Él es el único autor! ¡Muera el Cervantismo! ¡Viva el Quijotismo!

\footnotetext{
${ }^{9}$ Fragmento de la novela Quién (Barna: Editorial Destino, 1997).
} 
III. REALIDAD Y FICCIÓN: LA CONTINUA MUDANZA

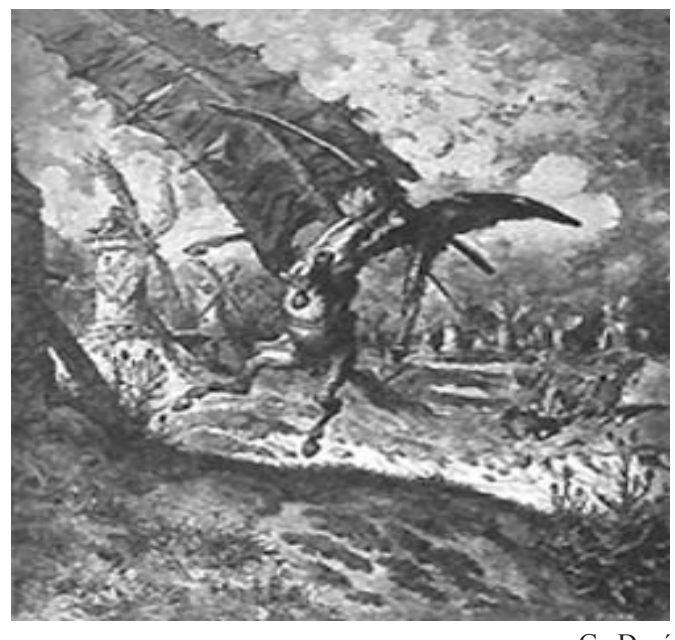

G. Doré.

"En esto descubrieron treinta o cuarenta molinos de viento que hay en aquel campo; y así como don Quijote los vio, dijo a su escudero:

- La ventura va guiando nuestras cosas mejor de lo que acertáramos a desear; porque ves allí, amigo Sancho Panza, donde se descubren treinta o pocos más desaforados gigantes, con quien pienso hacer batalla y quitarles a todos las vidas, con cuyos despojos comenzaremos a enriquecer; que ésta es buena guerra, y es gran servicio de Dios quitar tan mala simiente de sobre la faz de la tierra.

—¿Qué gigantes? — dijo Sancho Panza.

-Aquellos que allí ves — respondió su amo- de los brazos largos, que los suelen tener algunos de casi dos leguas.

-Mire vuestra merced — respondió Sancho- que aquellos que allí se parecen no son gigantes, sino molinos de viento, y lo que en ellos parecen brazos son las aspas, que, volteadas del viento, hacen andar la piedra del molino.

-Bien parece — respondió don Quijote — que no estás cursado en esto de las aventuras; ellos son gigantes, y si tienes miedo, quítate de ahí y ponte en oración en el espacio que yo voy a entrar con ellos en fiera y desigual batalla. 
Y, diciendo esto, dio de espuelas a su caballo Rocinante, sin atender a las voces que su escudero Sancho le daba, advirtiéndole que, sin duda alguna, eran molinos de viento, y no gigantes, aquellos que iba a acometer. Pero él iba tan puesto en que eran gigantes, que ni oía las voces de su escudero Sancho, ni echaba de ver, aunque estaba ya bien cerca, lo que eran; antes bien iba diciendo en voces altas:

-Non fuyades, cobardes y viles criaturas; que un solo caballero es el que os acomete.

Levantóse en esto un poco de viento, y las grandes aspas comenzaron a moverse, lo cual visto por don Quijote, dijo:

-Pues aunque mováis más brazos que los del gigante Briareo, me lo habéis de pagar.

Y en diciendo esto, y encomendándose de todo corazón a su señora Dulcinea, pidiéndole que en tal trance le socorriese, bien cubierto de su rodela, con la lanza en el ristre, arremetió a todo el galope de Rocinante, y embistió con el primero molino que estaba delante; y dándole una lanzada en el aspa, la volvió el viento con tanta furia, que hizo la lanza pedazos, llevándose tras sí al caballo y al caballero, que fue rodando muy maltrecho por el campo. Acudió Sancho Panza a socorrerle a todo el correr de su asno, y cuando llegó, halló que no se podía menear; tal fue el golpe que dio con él Rocinante.

—Válame Dios! —dijo Sancho—; ¿no le dije yo a vuestra merced que mirase bien lo que hacía, que no eran sino molinos de viento, y no lo podía ignorar sino quien llevase otros tales en la cabeza?

—Calla, amigo Sancho — respondió don Quijote—, que las cosas de la guerra, más que otras, están sujetas a continua mudanza; cuanto más, que yo pienso, y es así verdad, que aquel sabio Frestón que me robó el aposento y los libros ha vuelto estos gigantes en molinos por quitarme la gloria de su vencimiento: tal es la enemistad que me tiene; mas al cabo al cabo han de poder poco sus malas artes contra la bondad de mí espada.

-Dios lo haga como puede — respondió Sancho Panza; y ayudándole a levantar, tornó a subir sobre Rocinante, que medio despaldado estaba."

(Primera Parte, Cap. VIII, pp. 75-76.) 
La realidad y la ficción: constantes problemas que recorren las páginas de la novela de Cervantes desestabilizándose mutuamente, y que han sido objeto de un sinnúmero de comentarios y reflexiones; aquí recogemos sólo algunos de ellos. Para Vargas Llosa, la ficción es una mentira que encubre una enorme verdad: la vida que no fue; la ficción es, en suma, una reflexión sobre el individuo más que sobre el mundo. Nabokov enfatiza en lo infructuoso que resulta el ejercicio de buscar la conciliación entre la ficción de los hechos y los hechos de la ficción. Provechoso, por otra parte, sería ver cómo algunos de los elementos de la realidad se transmutan en arte, tocados por el ingenio del maestro, lo cual se relaciona con el breve comentario de Hume. También está Kafka, quien condensa en siete líneas sus propias obsesiones con una de las más profundas y enigmáticas miradas sobre la novela: la ficción es una trampa, se nos ofrece como una posibilidad de librarnos de los demonios de la realidad, disfrazándolos con un atuendo más amable que nos permita dejarnos conducir por ella y sus infinitas posibilidades, exentos de culpa, hasta una feliz disolución. Finalmente Foucault, para quien el Quijote marca el deslinde entre la escritura y el mundo: en la Segunda Parte, la novela se vuelca sobre sí misma, conduciendo hacia horizontes insospechados, en el contexto de la modernidad temprana.

\section{$* * *$}

\section{Cartas a un joven novelista ${ }^{10}$}

Mario Vargas Llosa (1936)

Parábola de la solitaria

La ficción es una mentira que encubre una profunda verdad; ella es la vida que no fue, la que los hombres y mujeres de una época dada quisieron tener y no tuvieron y por eso debieron inventarla.

Ahora bien, cuando alguien - por ejemplo, don Quijote o madame Bovary - se empeña en confundir la ficción con la vida, y trata de que la vida sea como ella aparece en las ficciones, el resultado suele ser dramático. Quien actúa así suele pagarlo en decepciones terribles.

Sin embargo, el juego de la literatura no es inocuo. Producto de una insatisfacción íntima contra la vida tal como es, la ficción es también fuente

${ }^{10}$ Tomado del ensayo Cartas a un joven novelista (Barcelona: Planeta, 1997). 
de malestar y de insatisfacción. Porque quien, mediante la lectura, vive una gran ficción - como esas dos que acabo de mencionar, la de Cervantes y la de Flaubert - regresa a la vida real con una sensibilidad mucho más alerta ante sus limitaciones e imperfecciones, enterado por aquellas magníficas fantasías de que el mundo real, la vida vivida, son infinitamente más mediocres que la vida inventada por los novelistas. Esa intranquilidad frente al mundo real que la buena literatura alienta, puede, en circunstancias determinadas, traducirse también en una actitud de rebeldía frente a la autoridad, las instituciones o las creencias establecidas.

\section{Introducción al Curso sobre el Quijote (Vida real y ficción) ${ }^{11}$}

Vladimir Nabokov (1899-1977)

Vamos a hacer todo lo posible por no caer en el fatídico error de buscar en las novelas la llamada "vida real". Vamos a no tratar de conciliar la ficción de los hechos con los hechos de la ficción. El Quijote es un cuento de hadas, como lo es Casa desolada, como lo es Almas muertas. Madame Bovary y Ana Karenina son cuentos de hadas excelsos. Pero sin estos cuentos de hadas el mundo no sería real. Una obra maestra de ficción es un mundo original, y en cuanto tal no es probable que coincida con el mundo del lector. Por otra parte, ¿qué es la tan cacareada "vida real", qué son los "hechos" ciertos?

La idea de "vida real" se basa en un sistema de generalidades, y si los llamados "hechos" de la llamada "vida real" enlazan con la obra de ficción es únicamente en cuanto generalidades. Por lo tanto, cuanto menos general sea una obra de ficción menos reconocible será en términos de "vida real". O viceversa, cuanto más detalles vívidos y nuevos haya en una obra de ficción, más se apartará ésta de la llamada "vida real", dado que la "vida real" es el epíteto generalizado, la emoción media, la multitud de los anuncios, el mundo del sentido común... Por otra parte, existe alguna correspondencia entre ciertas generalidades de la ficción y ciertas generalidades de la vida. Pensemos en el dolor físico o mental, por ejemplo, o en los sueños, o en la locura, o en cosas como la bondad, la misericordia, la justicia: pensemos en estos elementos generales de la vida humana, y estaremos de acuerdo en que sería provechoso estudiar de qué manera los maestros de la narrativa los transmutan en arte.

\footnotetext{
${ }^{11}$ Fragmento de la "Introducción", tomado de Curso sobre el Quijote (Edicio-
} nes B, Madrid: 2004). 


\section{La verdad sobre Sancho Panza ${ }^{12}$}

Franz Kafka (1883-1924)

Sancho Panza, que por lo demás nunca se jactó de ello, logró, con el correr de los años, mediante la composición de una cantidad de novelas de caballería y de bandoleros, en horas del atardecer y de la noche, apartar a tal punto de sí a su demonio, al que luego dio el nombre de don Quijote, que éste se lanzó irrefrenablemente a las más locas aventuras; las cuales, empero, por falta de un objeto predeterminado, y que precisamente hubiera debido ser Sancho Panza, no dañaron a nadie. Sancho Panza, hombre libre, siguió impasible, quizás en razón de cierto sentido de la responsabilidad, a don Quijote en sus andanzas, alcanzando con ello un grande y útil esparcimiento hasta su fin.

\section{Sobre la sencillez y el refinamiento en el arte de escribir ${ }^{13}$}

David Hume (1711-1773)

Los sentimientos que son meramente naturales no producen ningún placer en la mente y no merecen nuestra atención. Los chistes de un marinero, las observaciones de un campesino, las vulgaridades de un mozo de cuerda o de un cochero son expresiones tan naturales como desagradables. ¿No sería insípida una comedia que se limitara a copiar a la letra lo que se dice en una charla a la hora del té? Nada puede procurar placer a las personas de buen gusto como no sea la naturaleza adornada y perfeccionada por el arte, es decir, la belle nature. Y si nos inspiramos en la vida de los de la clase baja, las modificaciones artísticas deben ser vigorosas y notables, capaces de suscitar en el alma imágenes vívidas. La absurda naïveté de Sancho Panza está pintada por Cervantes de modo tan inimitable que nos entretiene lo mismo que si se tratara del héroe más grandioso o del más delicado personaje de novela de amor.

\footnotetext{
12 Texto completo de la parábola "La verdad sobre Sancho Panza", tomado de La muralla china: cuentos, relatos y otros escritos (Madrid: Alianza Editorial, 1973).

${ }^{13}$ Tomado de Sobre la sencillez y el refinamiento en el arte de escribir (Madrid: Alianza Editorial, 1983).
} 


\section{Las palabras y las cosas ${ }^{14}$ \\ Michel Foucault (1926-1984)}

\section{Don Quijote}

Con todas sus vueltas y revueltas, las aventuras de Don Quijote trazan el límite: en ellas terminan los juegos antiguos de la semejanza y de los signos; allí se anudan nuevas relaciones. Don Quijote no es el hombre extravagante, sino más bien el peregrino meticuloso que se detiene en todas las marcas de la similitud. Es el héroe de lo Mismo. Así como de su estrecha provincia, no logra alejarse de la planicie familiar que se extiende en torno a lo Análogo. La recorre indefinidamente, sin traspasar jamás las claras fronteras de la diferencia, ni reunirse con el corazón de la identidad. Ahora bien, él mismo es a semejanza de los signos. Largo grafismo flaco como una letra, acaba de escapar directamente del bostezo de los libros. Todo su ser no es otra cosa que lenguaje, texto, hojas impresas, historia ya transcrita. Está hecho de palabras entrecruzadas; pertenece a la escritura errante por el mundo entre la semejanza de las cosas. Sin embargo, no del todo: pues en su realidad de hidalgo pobre, no puede convertirse en caballero sino escuchando de lejos la epopeya secular que formula la Ley. El libro es menos su existencia que su deber. Ha de consultarlo sin cesar a fin de saber qué hacer y qué decir y qué signos darse a sí mismo y a los otros para demostrar que tiene la misma naturaleza que el texto del que ha surgido. Las novelas de caballería escribieron de una vez por todas las prescripciones de su aventura.

Y cada episodio, cada decisión, cada hazaña serán signos de que Don Quijote es, en efecto, semejante a todos esos signos que ha calcado.

Pero si quiere ser semejante a ellos, tiene que probarlos, porque los signos (legibles) no se asemejan ya a los seres (visibles). Todos estos textos escritos, todas estas novelas extravagantes carecen justamente de igual: nada en el mundo se les ha asemejado jamás: su lenguaje infinito queda en suspenso, sin que ninguna similitud venga nunca a llenarlo; podrían arder por completo, la figura del mundo no cambiaría. Al asemejarse a los textos de los cuales es testigo, representante, análogo verdadero, Don Quijote debe proporcionar la demostración y ofrecer la marca indudable de que dicen verdad, de que son el lenguaje del mundo. Es asunto suyo el cumplir la promesa de los libros. Tiene que rehacer la epopeya, pero en sentido inverso: ésta relataba (pretendía relatar) hazañas reales, prometidas a la memoria; Don Quijote, en cambio, debe colmar de realidad los signos sin contenido del relato. Su aventura será un desciframiento del mundo: un

14 Tomado de Las palabras y las cosas, traducción de Elsa Cecilia Frost (México: Siglo Veintiuno Editores, México, 1999). 
recorrido minucioso para destacar, sobre toda la superficie de la tierra, las figuras que muestran que los libros dicen la verdad. La hazaña tiene que ser comprobada: no consiste en un triunfo real $-\mathrm{y}$ por ello la victoria carece, en el fondo, de importancia-, sino en transformar la realidad en signo. En signo de que los signos del lenguaje se conforman con las cosas mismas. Don Quijote lee el mundo para demostrar los libros. Y no se da otras pruebas que el reflejo de las semejanzas.

Todo su camino es una búsqueda de similitudes: las más mínimas analogías son solicitadas como signos adormecidos que deben ser despertados para que empiecen a hablar de nuevo. Los rebaños, los sirvientes, las posadas se convierten de nuevo en el lenguaje de los libros en la medida imperceptible en que se asemejan a los castillos, a las damas, a los ejércitos. Semejanza siempre frustrada que transforma la prueba buscada en burla y deja indefinidamente vacía la palabra de los libros. Pero la no similitud misma tiene un modelo que imita servilmente: lo encuentra en las metamorfosis de los magos. En tal medida que todos los indicios de la no semejanza, todos los signos que muestran que los textos escritos no dicen la verdad, se asemejan a este juego de encantamiento que introduce astutamente la diferencia en lo indudable de la similitud. Y dado que esta magia ha sido prevista y descrita en los libros, la diferencia ilusoria que introduce será siempre una similitud encantada. En consecuencia, un signo suplementario de que los signos se asemejan a la verdad.

Don Quijote esboza lo negativo del mundo renacentista; la escritura ha dejado de ser la prosa del mundo; las semejanzas y los signos han roto su viejo compromiso; las similitudes engañan, llevan a la visión y al delirio; las cosas permanecen obstinadamente en su identidad irónica: no son más que lo que son; las palabras vagan a la aventura, sin contenido, sin semejanza que las llene; ya no marcan las cosas; duermen entre las hojas de los libros en medio del polvo. La magia, que permitía el desciframiento del mundo al descubrir las semejanzas secretas bajo los signos, sólo sirve ya para explicar de modo delirante por qué las analogías son siempre frustradas. La erudición que leía como un texto único la naturaleza y los libros es devuelta a sus quimeras: depositados sobre las páginas amarillentas de los volúmenes, los signos del lenguaje no tienen ya más valor que la mínima ficción de lo que representan. La escritura y las cosas ya no se asemejan. Entre ellas, Don Quijote vaga a la aventura.

Sin embargo, el lenguaje no se ha convertido en algo del todo impotente. Detenta, de ahora en adelante, nuevos poderes que le son propios. En la segunda parte de la novela, Don Quijote encuentra personajes que han leído la primera parte del texto y que lo reconocen, a él, el hombre real, como el héroe del libro. El texto de Cervantes se repliega sobre sí mismo, se hunde en su propio espesor y se convierte en objeto de su propio relato 
para sí mismo. La primera parte de las aventuras desempeña en la segunda el papel que asumieron al principio las novelas de caballería. Don Quijote debe ser fiel a este libro en el que, de hecho, se ha convertido; debe protegerlo contra los errores, las falsificaciones, las continuaciones apócrifas; debe añadir los detalles omitidos, debe mantener su verdad. Pero el propio Don Quijote no ha leído este libro y no podrá hacerlo, puesto que es él en carne y hueso. Él, que a fuerza de leer libros, se había convertido en un signo errante en un mundo que no lo reconoce, se ha convertido ahora, a pesar de sí mismo y sin saberlo, en un libro que detenta su verdad, recoge exactamente todo lo que él ha hecho, dicho, visto y pensado y permite, en última instancia, que se le reconozca en la medida en que se asemeja a todos estos signos que ha dejado tras sí como un surco imborrable. Entre la primera y la segunda partes de la novela, en el intersticio de estos dos volúmenes y por su solo poder, Don Quijote ha tomado su realidad. Realidad que sólo debe al lenguaje y que permanece por completo en el interior de las palabras. La verdad de Don Quijote no está en la relación de las palabras con el mundo, sino en esta tenue y constante relación que las marcas verbales tejen entre ellas mismas. La ficción frustrada de las epopeyas se ha convertido en el poder representativo del lenguaje. Las palabras se encierran de nuevo en su naturaleza de signos.

Don Quijote es la primera de las obras modernas, ya que se ve en ella la razón cruel de las identidades y de las diferencias juguetear al infinito con los signos y las similitudes; porque en ella el lenguaje rompe su viejo parentesco con las cosas para penetrar en esta soberanía solitaria de la que ya no saldrá, en su ser abrupto, sino convertido en literatura; porque la semejanza entra allí en una época que es para ella la de la sinrazón y de la imaginación. Una vez desatados la similitud y los signos, pueden constituirse dos experiencias y dos personajes pueden aparecer frente a frente. El loco, entendido no como enfermo, sino como desviación constituida y sustentada, como función cultural indispensable, se ha convertido, en la cultura occidental, en el hombre de las semejanzas salvajes. Este personaje, tal como es dibujado en las novelas o en el teatro de la época barroca y tal como se fue institucionalizando poco a poco hasta llegar a la psiquiatría del siglo XIX, es el que se ha enajenado dentro de la analogía. Es el jugador sin regla de lo Mismo y de lo Otro. Toma las cosas por lo que no son y unas personas por otras; ignora a sus amigos, reconoce a los extraños; cree desenmascarar e impone una máscara. Invierte todos los valores y todas las proporciones porque en cada momento cree descifrar los signos: para él, los oropeles hacen un rey. Dentro de la percepción cultural que se ha tenido del loco hasta fines del siglo XVII, sólo es el Diferente en la medida en que no conoce la Diferencia; por todas partes ve únicamente semejanzas y signos 
de la semejanza; para él todos los signos se asemejan y todas las semejanzas valen como signos. En el otro extremo del espacio cultural, pero muy cercano por su simetría, el poeta es el que, por debajo de las diferencias nombradas y cotidianamente previstas, reencuentra los parentescos huidizos de las cosas, sus similitudes dispersas. Bajo los signos establecidos, y a pesar de ellos, oye otro discurso, más profundo, que recuerda el tiempo en el que las palabras centelleaban en la semejanza universal de las cosas: la Soberanía de lo mismo, tan difícil de enunciar, borra en su lenguaje la distinción de los signos.

De allí proviene, sin duda, en la cultura occidental moderna, el enfrentamiento de la poesía y la locura. Pero no se trata ya del viejo tema platónico del delirio inspirado. Es la marca de una nueva experiencia del lenguaje y de las cosas. En los márgenes de un saber que separa los seres, los signos y las similitudes, y como para limitar su poder, el loco asegura la función del homosemantismo: junta todos los signos y los llena de una semejanza que no para de proliferar. El poeta asegura la función inversa; tiene el papel alegórico; bajo el lenguaje de los signos y bajo el juego de sus distinciones bien recortadas, trata de oír el "otro lenguaje", sin palabras ni discursos, de la semejanza. El poeta hace llegar la similitud hasta los signos que hablan de ella, el loco carga todos los signos con una semejanza que acaba por borrados. Así, los dos —uno en el borde exterior de nuestra cultura y el otro en lo más cercano a sus partes esenciales - están en esta "situación límite" - postura marginal y silueta profundamente arcaica - en la que sus palabras encuentran incesantemente su poder de extrañeza y el recurso de su impugnación. Entre ellos se ha abierto el espacio de un saber en el que, por una ruptura esencial en el mundo occidental, no se tratará ya de similitudes, sino de identidades y de diferencias.

\section{Mi entrañable señor Cervantes ${ }^{15}$}

Jorge Luis Borges (1899-1986)

Pero, por supuesto, durante todo el libro, especialmente en la primera parte, el conflicto es muy brutal y obvio. Vemos a un caballero que vaga en sus empresas filantrópicas a través de los polvorientos caminos de España, siempre apelado y en apuros. Además de eso, encontramos muchos indicios de la misma idea. Porque, por supuesto, Cervantes era un hombre demasiado sabio como para no saber que, aun cuando opusiera los sueños y

${ }^{15}$ Fragmento de la conferencia "Mi entrañable señor Cervantes", tomado de la revista Papel literario de El Nacional, $1^{\circ}$ de agosto de 1999. 
la realidad, la realidad no era, digamos, la verdadera realidad, o la monótona realidad común. Era una realidad creada por él; es decir, la gente que representa la realidad en Don Quijote forma parte del sueño de Cervantes tanto como Don Quijote y sus infladas ideas de la caballerosidad, de defender a los inocentes y demás. Y a lo largo de todo el libro hay una suerte de mezcla de los sueños y la realidad.

Por ejemplo, se puede señalar un hecho, y me atrevo a decir que ha sido señalado con mucha frecuencia, ya que se han escrito tantas cosas sobre Don Quijote. Es el hecho de que, tal como la gente habla todo el tiempo del teatro en Hamlet, la gente habla todo el tiempo de libros en Don Quijote. Cuando el párroco y el barbero revisan la biblioteca de Don Quijote, descubrimos, para nuestro asombro, que uno de los libros ha sido escrito por Cervantes, y sentimos que en cualquier momento el barbero y el párroco pueden encontrarse con un volumen del mismo libro que estamos leyendo. En realidad eso es lo que pasa, tal vez lo recuerden, en ese otro espléndido sueño de la humanidad, el libro de Las mil y una noches. Pues en medio de la noche Scherezade empieza a contar distraídamente una historia y esa historia es la historia de Scherezade. Y podríamos seguir hasta el infinito. Por supuesto, esto se debe a, bueno, a un simple error del copista que vacila ante ese hecho, si Scherezade contando la historia de Scherezade es tan maravilloso como cualquier otro de los maravillosos cuentos de las Noches.

Además, también tenemos en Don Quijote el hecho de que muchas historias están entrelazadas. Al principio podemos pensar que se debe a que Cervantes puede haber pensado que sus lectores podrían cansarse de la compañía de Don Quijote y de Sancho y entonces trató de entretenerlos entrelazando otras historias. Pero yo creo que lo hizo por otra razón. Y esa otra razón sería que esas historias, la novela del Curioso impertinente, el cuento del cautivo y demás, son otras historias. Y por eso está esa relación de sueños y realidad, que es la esencia del libro. Por ejemplo, cuando el Cautivo nos cuenta su cautiverio, habla de un compañero. $Y$ ese compañero, se nos hace sentir, es finalmente nada menos que Miguel de Cervantes Saavedra, que escribió el libro. Así hay un personaje que es un sueño de Cervantes y que, a su vez, sueña con Cervantes y lo convierte en un sueño . . . Entonces tenemos en Don Quijote un doble carácter. Realidad y sueño. Pero al mismo tiempo Cervantes sabía que la realidad estaba hecha de la misma materia que los sueños. Es lo que debe haber sentido. Todos los hombres lo sienten en algún momento de su vida. Pero él se divirtió recordándonos que aquello que tomamos como pura realidad era también un sueño. Y así todo el libro es una suerte de sueño. Y al final sentimos que, después de todo también nosotros podemos ser un sueño. 


\section{IMITACIÓN Y LOCURAS}

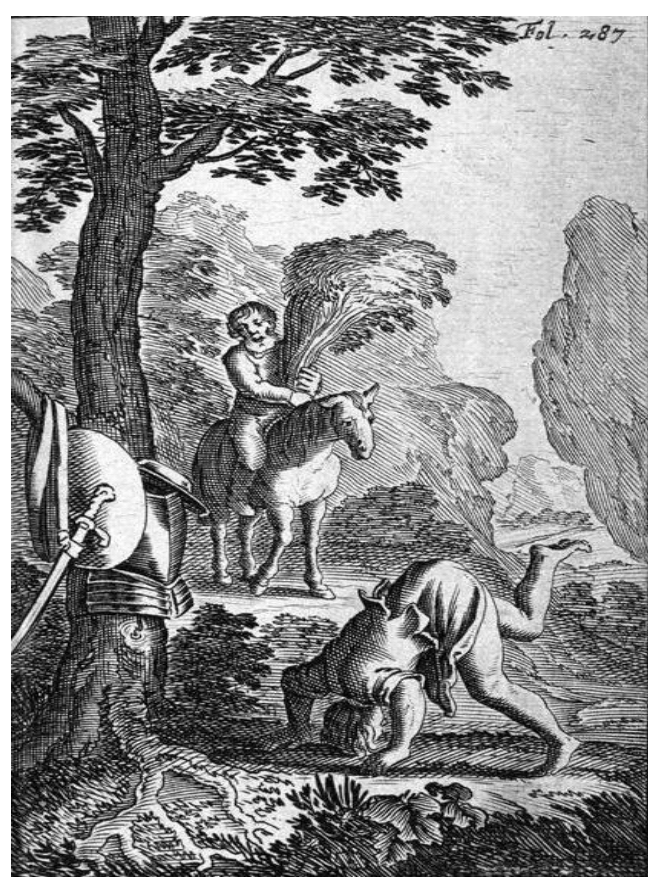

Dordrecht, 1657

“-En efecto — dijo Sancho-, ¿qué es lo que vuestra merced quiere hacer en este tan remoto lugar?

- ¿Ya no te he dicho — respondió don Quijote- que quiero imitar a Amadís, haciendo aquí del desesperado, del sandio y del furioso, por imitar juntamente al valiente don Roldán, cuando halló en una fuente las señales de que Angélica la Bella había cometido vileza con Medoro, de cuya pesadumbre se volvió loco, y arrancó los árboles, enturbió las aguas de las claras fuentes, mató pastores, destruyó ganados, abrasó chozas, derribó casas, arrastró yeguas y hizo otras cien mil insolencias, dignas de eterno nombre y escritura? Y, puesto que yo no pienso imitar a Roldán, o Orlando, o Rotolando, que todos estos tres nombres tenía, parte por parte en todas las locuras que hizo, dijo y pensó, haré el bosquejo como mejor pudiere en las que me pareciere ser más esenciales. Y podrá ser que 
viniese a contentarme con sola la imitación de Amadís, que sin hacer locuras de daño, sino de lloros y sentimientos, alcanzó tanta fama como el que más.

-Paréceme a mí —dijo Sancho_, que los caballeros que lo tal ficieron fueron provocados y tuvieron causa para hacer esas necedades y penitencias; pero vuestra merced ¿qué causa tiene para volverse loco? ¿Qué dama le ha desdeñado, o qué señales ha hallado que le den a entender que la señora Dulcinea del Toboso ha hecho alguna niñería con moro o cristiano?

—Ahí está el punto — respondió don Quijote-, y ésa la fineza de mi negocio; que volverse loco un caballero andante con causa, ni grado ni gracias: el toque está en desatinar sin ocasión y dar a entender a mi dama que, si en seco hago esto, ¿qué hiciera en mojado?"

(Primera Parte, Cap. XXV, pp. 235-236.)

\section{$* * *$}

Sierra Morena marca para la parodia caballeresca la gratuidad en don Quijote. La decisión sobre a quién imitar no tiene causa, es sólo el mostrar; locura que parte de la razón y que por eso es mayor locura.

La pareja se había internado fuera de los caminos para evitar a la Santa Hermandad, pero don Quijote ve la oportunidad de continuar su libro con otra de las circunstancias propias de sus modelos, principalmente de Amadís en Peña Pobre, desdeñado por Oriana: locuras de amor. La lectura de los libros crea el deseo de imitación, sobre todo de las situaciones extremas, tipificadas. La influencia de la ficción en nuestras vidas, las vidas fingidas, el ánimo heroico, la parodia o no, los juegos o no, la conciencia o no, se hicieron carne de grandes novelistas, lectores todos de don Quijote.

En las llamadas por Casalduero "aventuras del mundo moderno", la pareja de caballero y escudero (cap. XVIII-XXIII) se encuentra ante un mundo diferente (para algunos, el mundo Barroco, donde las ilusiones de la realidad se hacen presentes como engaño a los ojos). Este conjunto de aventuras muestra además un acercamiento extremo de la pareja, en el que los límites se pierden. Los personajes vomitan uno sobre el otro. Sancho carga a su amo sobre Rocinante, engaña a su amo la noche anterior atándole las patas a Rocinante, narra su primer cuento (que es burlesco, "de nunca acabar"), defeca abrazado a la pierna de su amo, se ríe de él, lo imita ridículamente. Todo concluye con la imposición de silencio que don Quijote hace a 
Sancho. Sin embargo, adrede o no, la crítica se ha empecinado con alguna razón en ver este conjunto de aventuras como el inicio de lo que se llamó sanchificación y quijotización de los personajes.

Los mundos imaginarios y actuantes de ambos personajes comienzan a fundirse. Cada vez más Sancho se adentra en los sucesos caballerescos y cada vez más don Quijote se pliega al mundo de Sancho. Ambos, vistos desde las oposiciones, empiezan a cambiar, se hacen un algo diferente, se unen novelísticamente, se hacen pareja. Las ideas en la ficción posterior proliferaron a partir de esta relación de contrastes y no tanto.

\section{El poeta asesinado ${ }^{16}$ \\ Guillaume Apollinaire (1880-1918)}

También le hizo leer las traducciones de Cervantes y Goethe. Siguiendo su consejo, Croniamantal leyó novelas de caballería de las que varias hubieran podido formar parte de la biblioteca de Don Quijote. Desarrollaron en Croniamantal un deseo insuperable de aventuras y amores peligrosos. Practicaba la esgrima, la equitación. Desde los quince años declaraba a cualquiera que fuera a verle que estaba absolutamente decidido a convertirse en un famoso caballero sin par, y ya soñaba con una amante.

\section{La historia de Tom Jones ${ }^{17}$}

Henry Fielding (1707-1754)

Habiendo agotado la costa entera del enemigo, así como cualquiera de los héroes de Homero alguna vez hizo, o como Don Quijote o cualquier caballero-errante en el mundo podría hacer, él retornó a Molly, a quien encontró en una condición que hubiese producido, tanto a mí como a mi lector, dolor, y que procederé a describir. Tom deliró como un loco, golpeó su pecho, rasgó su pelo estampillándolo en la tierra, y juró la venganza

\footnotetext{
${ }^{16}$ Tomado de la novela El poeta asesinado (Barcelona: Macondo Ediciones, Editorial Lumen, 1969).

${ }^{17}$ Tomado del libro IV de la novela The History of Tom Jones, A Foundling, Fredson Bowers, editor, Wesleyan Edition of the Works of Henry Fielding, 2 vols. (Oxford: Oxford University Press, 1975). Traducción de Miguel Payer.
} 
suma a todos los implicados. Tiró entonces fuera su chaqueta, desabrochó los botones, puso su sombrero en la cabeza de ella, limpió la sangre de su cara como pudo con su pañuelo, e instó al sirviente a cabalgar tan rápido como fuera posible, para que la llevase pronto a casa y a salvo.

\section{Vida y opiniones del caballero Tristram Shandy ${ }^{18}$}

\section{Laurence Sterne (1713-1768)}

Espíritu amable del más fragante humor que haya inspirado nunca la fácil pluma de mi idolatrado Cervantes. Tú que te has deslizado cada día a través de su reja convirtiéndolo con tu presencia en sol radiante la luz crepuscular de su prisión. Tú que has teñido el agua de su jarra con el néctar celestial y que durante todo el tiempo en que escribió sobre Sancho y su amo desplegaste sobre él, sobre su mustio muñón y sobre todos los males de su vida tu manto místico.

¡Vuelve hacia mí tus ojos, te lo imploro! ¡Contempla mis calzones! Son todo lo que tengo en este mundo. Ese lastimoso rasgón me lo hicieron en Lyon.

\section{Las aventuras de Huckleberry Finn ${ }^{19}$}

Mark Twain (1835-1910)

Un día Tom envió a uno de los muchachos a recorrer el pueblo con una antorcha encendida (ésta era la señal convenida para que todos acudiéramos con urgencia a la cueva) y luego era para decirnos que sus espías le habían proporcionado la información secreta de que al día siguiente una cuadrilla de mercaderes españoles y árabes ricos iban a acampar en Cave Hollow, con una caravana de doscientos elefantes y seiscientos camellos, y más de mil "cabalgaduras" rebosantes de diamantes, y que además sólo venían escoltados por una guardia de unos cuatrocientos soldados. Por lo tanto, podríamos prepararles lo que él llamaba una emboscada, les mataríamos a todos, quedándonos con las riquezas. Nos recomendó que puliéramos bien las espadas y los rifles y estuviéramos listos para el asalto. Nunca consintió en atacar a una sola carreta de verduras sin habernos hecho antes limpiar bien las espadas y fusiles, aunque no eran más que trozos de hojala-

${ }^{18}$ Tomado de la novela Vida y opiniones del caballero Tristram Shandy (Ed. Cátedra, 1990).

${ }^{19}$ Tomado de la novela Las aventuras de Huckleberry Finn (Madrid: Editorial Dintel, 1982). 
ta y palos de escoba, y ya podía uno frotar hasta hartarse, que no por ello dejaban de ser lo que eran ni ganaban en absoluto. Yo no creí ni por un momento que fuéramos a vencer contra una multitud semejante de españoles y árabes, pero me hacía ilusión lo de ver camellos y elefantes, así que el sábado estaba yo como un clavo en mi puesto en la emboscada. Cuando recibimos la señal salimos corriendo cuesta abajo por el bosque. Pero al llegar no encontramos ni españoles, ni árabes, ni camellos, ni elefantes. No se trataba más que de una excursión de niños de primer grado de la escuela dominical. Embestimos sobre ellos, y les hicimos huir ladera abajo, y como único botín sólo conseguimos unas cuantas rosquillas y mermelada, aunque Ben Rogers logró además apoderarse de una muñeca de trapo y Joe Harper de un libro de himnos y un folleto.

Pero para colmo nos dio alcance la maestra y nos obligó a soltar todo lo que habíamos cogido. Y así acabó todo. Yo no había visto ni el menor asomo de diamante, y así se lo dije a Tom Sawyer, que me repuso que los había a montones, así como árabes, elefantes y todas las demás cosas.

— Si es verdad — le dije—, ¿cómo es que no se ven?

Me replicó que si yo no fuera tan ignorante y hubiera leído un libro titulado Don Quijote sabría la respuesta sin necesidad de hacer preguntas tan tontas. Me explicó que todo se había transformado por arte de encantamiento. Y me aseguró que allí había cientos de soldados, de tesoros, y de elefantes, pero que nuestros enemigos, a los que él llamaba magos, lo habían convertido en una excursión de niños de la escuela dominical, sólo por despecho.

—Bueno - le dije yo entonces-, pues lo que deberíamos hacer es perseguir a los magos esos.

Tom Sawyer me dijo que no era más que un zoquete.

\section{Monseñor Quijote ${ }^{20}$}

Graham Greene (1904-1991)

El padre Quijote tenía motivos para temer a los obispos; era muy consciente de la gran antipatía que sentía por él su propio obispo, quien le consideraba poco más que un campesino, pese a su eminente antecesor. — ¿Cómo puede descender de un personaje de ficción? — había preguntado el obispo en una conversación privada de la que puntualmente fue informado el padre Quijote.

${ }^{20}$ Tomado de Monseñor Quijote (Madrid: Editorial Gredos, 1958). 
El hombre con quien el obispo conversaba contestó, sorprendido:

— ¿Un personaje de ficción?

-Un personaje de una novela de un escritor sobrestimado que se llamaba Cervantes; más aún, una novela con muchos pasajes que en los tiempos del Generalísimo ni siquiera hubieran pasado la censura.

-Pero, Excelencia, ahí tiene usted la casa de Dulcinea en El Toboso. Allí lo tiene escrito en una placa: casa de Dulcinea.

-Un reclamo para turistas. Pero bueno — prosiguió el obispo ásperamente-, Quijote no es siquiera un patronímico español. Cervantes mismo dice que probablemente se apellidaba Quijada o Quesada, o incluso Quejana, y en su lecho de muerte el Quijote se llama a sí mismo Quijano.

- Veo que Su Excelencia ha leído el libro.

-Nunca he pasado del primer capítulo. Claro que, desde luego, he echado un vistazo al último. Eso suelo hacer con las novelas.

—Quizás algún antepasado del padre Quijote se llamaba Quijada o Quejana.

—Los hombres de esa clase no tienen antepasados.

\section{El viaje 21 $^{21}$ \\ Washington Irving (1783-1859)}

En la ocasión presente extendió en el verde césped, delante de nosotros, gran variedad de sobras, colmadas con un buen jamón que habíamos traído de Sevilla; luego, tomando asiento a corta distancia, se dedicó a disfrutar de lo que todavía quedaba en las alforjas. Un tiento o dos a la bota le pusieron tan contento y cantarín como una cigarra ahíta de rocío. Al comparar el contenido de sus alforjas con los estragos que Sancho hizo en las ollas de las bodas de Camacho, pude comprobar que estaba bien versado en la historia de don Quijote, pero que, al igual que mucha gente del vulgo español, creía firmemente que se trataba de una historia verdadera.

-Pero todo eso, señor, ocurrió hace mucho tiempo, ¿verdad?

- Mucho tiempo - contesté.

- Yo diría que más de mil años - añadió como si durara todavía. El escudero quedó tranquilo. Nada servía de mayor contento al bueno de

${ }^{21}$ Fragmento del relato "El viaje", tomado de Cuentos de la Alhambra (Buenos Aires: Acme, 1975). 
nuestro criado que el hecho de que le comparáramos al famoso Sancho en su afición a la despensa, y no se llamó a sí mismo por otro nombre durante todo el viaje.

\section{La mentira se salva por otra mentira ${ }^{22}$}

Feodor Dostoievski (1821-1881)

Un día Don Quijote, el caballero tan conocido, el más magnánimo caballero que jamás haya existido, vagabundeando con su fiel escudero Sancho, tuvo un ataque de perplejidad. Había leído que sus predecesores de los tiempos antiguos, por ejemplo, Amadís de Gaula, habían tenido a veces que luchar durante años enteros con cien mil soldados enviados contra ellos por las potencias infernales o los magos. Ordinariamente, un caballero que tropieza con semejante ejército de réprobos saca su espada, invoca en su ayuda el nombre de su dama y se lanza solo en medio de sus enemigos, a los que extermina, sin dejar uno. Todo esto estaba bien claro; pero aquel día, Don Quijote permaneció pensativo. ¿Cómo querían que un caballero, por fuerte y valiente que fuese, exterminase a cien mil adversarios en un solo combate de veinticuatro horas? Se necesita tiempo para matar a cada hombre; para matar a cien mil hace falta un tiempo inmenso. ¿Cómo podía ocurrir todo aquello?

"Ya he salido de mi perplejidad, amigo Sancho, dijo al fin Don Quijote; esos ejércitos eran diabólicos; por lo tanto imaginarios; los hombres que los componían no eran más que una creación de la magia; sus cuerpos no se parecían a los nuestros; tenían más analogía con los de los moluscos, los gusanos o las arañas, de tal modo que la espada de los caballeros los cortaba de un solo golpe sin encontrar más resistencia que la del aire. Y siendo así, podían matar tres, cuatro y hasta diez de esos guerreros de una sola estocada. Así es como resultaba fácil deshacerse, en algunas horas, de ejércitos de ese género".

En esto, el autor de Don Quijote, gran poeta y profundo observador del corazón humano, ha comprendido uno de los aspectos más misteriosos de nuestros espíritus. Ya no se escriben libros como aquel. Veréis en Don Quijote, en cada página, revelados los más secretos arcanos del alma humana. Notad que ese Sancho, el escudero, es la personificación del buen senti-

${ }^{22}$ Fragmento de "La mentira se salva por otra mentira", tomado del Diario de un escritor (Madrid: Editorial Espasa Calpe, 1960). 
do, de la prudencia, de la astucia, y que, sin embargo, se ha convertido en compañero del hombre más loco del mundo; iprecisamente él, y ningún otro! A cada instante engaña a su amo, lo engaña como a un niño pequeño; pero al mismo tiempo se siente lleno de admiración por la grandeza de su corazón y cree reales todos sus sueños fantásticos; no duda ni un minuto el que su amo no llegue a conquistarle una ínsula.

Es de desear que nuestra juventud adquiera un serio conocimiento de las grandes obras de la literatura universal. Yo no sé lo que les enseñan hoy a los jóvenes como literatura, pero el estudio de Don Quijote, uno de los libros más geniales y también de los más tristes que haya producido el genio humano, es muy capaz de educar la inteligencia de un adolescente. Verá allí, entre otras cosas, que las más hermosas cualidades del hombre pueden llegar a ser inútiles, excitar la risa de la Humanidad, si el que las posee no sabe penetrar el sentido verdadero de las cosas y hallar la "palabra nueva" que debe pronunciar...

Aparte de eso, yo no he querido decir más que una cosa; a saber: que el hombre que puso en acción los sueños más locos, los más fantásticos, llega de pronto a la duda y a la perplejidad. Toda su fe ha desaparecido, y no porque lo absurdo de su locura le haya sido revelado, sino porque una circunstancia secundaria aclara momentáneamente su inteligencia. Este hombre de ideas de otro mundo experimenta súbitamente la nostalgia de lo real. Si libros que él venera como verídicos le han engañado una vez, pueden engañarle siempre; quizá todo lo que contienen es mentira. ¿Cómo volver a la verdad? Cree volver a ella imaginando un absurdo mayor que el primero. Los centenares de miles de hombres evocados por los magos tendrán cuerpos de moluscos, y la espada del buen caballero trabajará diez veces más deprisa en su faena. Su necesidad de semejanza quedará satisfecha. Tendrá derecho a creer en el primer sueño gracias al segundo, mucho más ridículo.

Interrogaos a vosotros mismos y ved si cien veces no os ha ocurrido lo mismo. ¿Os habéis sentido enamorados de una idea, de un proyecto, de una mujer? ¿Habéis tenido una duda? Os habéis cuidado de crearos una ilusión más engañosa que la primera, que os habrá permitido continuar estando enamorados y desprenderos de la duda. 


\section{El mito de Sísifo ${ }^{23}$ \\ Albert Camus (1913-1960)}

Juzgo, pues, que el sentido de la vida es la más apremiante de las cuestiones. ¿Cómo responder a ella? En todos los problemas esenciales, y me refiero a los que ponen en peligro la vida o decuplican la pasión de vivir, no hay probablemente sino dos métodos de pensamiento, el de Perogrullo y el de don Quijote. El equilibrio de evidencia y lirismo es lo único que nos permite acceder al mismo tiempo a la emoción y la claridad. En un tema a la vez tan humilde y tan preñado de patetismo la dialéctica sabia y clásica debe ceder, pues, su lugar, parece claro, a una actitud anímica más modesta que procede a la vez del buen sentido y la simpatía.

\section{¡Ah, la ordenación social! ${ }^{24}$ \\ Camilo José Cela (1916-2002)}

No creemos que nadie - $\mathrm{y}$ en este nadie van incluidos, naturalmente los sociólogos-, que nadie en el mundo sepa, bien sabido, como quería Descartes, qué es lo que es eso de la ordenación social. Desde que el género humano existe y es posible que aun antes, la cuestión social no está lo que pudiéramos decir muy ordenada. La cosa es triste y probablemente muy de lamentar, pero lo cierto es que, querámoslo o no, es así y por lo que se ve no hay manera de variarla. Dios nos libre de preconizar soluciones para lo que creemos que no la tiene. Las soluciones, en este caso, lejos de serlo, se nos antojan complicaciones, dilaciones, aplazamientos e incluso, ¿por qué no decirlo?, traiciones. El mal tiene un vicio de origen, una tara de cuna, y los que han venido pensando en arreglarlo no se han dado cuenta, por lo común, de que no es problema para resolver sobre la serie de bases falsas desde las que se plantea. En psiquiatría hay un tipo de locura - concretamente la locura de Don Quijote - que viene caracterizada, sobre poco más o menos, por levantar todo un artilugio de una lógica perfecta e incluso aplastante, sobre un punto de vista inexistente o absurdo. Es claro que todo lo que hizo el andante caballero manchego en sus correrías es algo que puede responder con decoro al más exigente sentido común; lo que ya

\footnotetext{
${ }^{23}$ Tomado del ensayo El mito de Sísifo (Madrid: Alianza Editorial, 1999).

${ }^{24}$ Fragmento de “¡Ah!, la ordenación social!”, tomado de Las compañías convenientes y otros fingimientos y cegueras (Barcelona: Ediciones Destino, 1981).
} 
no parece, sin embargo, tan preciso es que en su tiempo se pudiese andar a caballo por los campos castellanos, desfaciendo entuertos, defendiendo viudas, y vestido de extraña guisa, sin ser apaleado, aporreado o apedreado por los atónitos indígenas.

Pues bien: con la llamada cuestión social - y con su corolario la ordenación social - pasa, grosso modo, una cosa muy parecida. La cuestión existe, el problema acucia, las soluciones propuestas, aunque fallan, no carecen de lógica, pero, ¡ay!, la cosa se plantea fuera de sus límites.

\section{Lecciones sobre la estética ${ }^{25}$ \\ Georg Wilhem Friedrich Hegel (1770-1821)}

Estos vicios de la caballería acarrean su ruina. Encontramos el cuadro más fiel de ellos en el poema de Ariosto y en el libro de Cervantes.

Lo que divierte principalmente en el Ariosto es el modo cómo los hechos, los personajes y sus empresas se cruzan y se entrelazan; el laberinto de narraciones en que se suceden en un cuadro movible una multitud de relaciones fantásticas y de situaciones cómicas con las que el poeta juega a la aventura hasta la frivolidad. Es una broma y una locura perpetua que los héroes deben tomar en serio. El amor, principalmente, cae de las puras regiones del amor divino de Dante y de la tendencia ideal de Petrarca a historias obscenas y colisiones risibles. Al mismo tiempo, el heroísmo y la bravura se exageran de tal modo, que, en vez de excitar la admiración, sin excluir la creencia, provocan la risa por el carácter fabuloso de todas esas hazañas. Pero, a pesar del modo raro con que se llevan las situaciones como las luchas y los conflictos se ponen en escena, empiezan, se interrumpen y reanudan, luego se cortan de nuevo y terminan finalmente con un desenlace inesperado, con su manera cómica de tratar la caballería, Ariosto sabe, sin embargo, conservar y hacer resaltar lo que ésta tiene de noble, los sentimientos generosos, el amor, el honor, la bravura, de igual modo que brilla en la pintura de las cualidades de otro género, la finura, la astucia, la presencia de espíritu, etc.

Si la manera de Ariosto es el cuento, la obra de Cervantes tiene más de la novela. Don Quijote es una noble naturaleza; la caballería le ha vuelto

\footnotetext{
25 Tomado de Lecciones sobre la estética (Madrid: Mestas Ediciones, 2003), Segunda parte, tercera sección, II, B.
} 
loco, porque con su carácter aventurero se encuentra colocado en medio de una sociedad organizada, en que todo está reglamentado. Esto da lugar a la contradicción cómica entre un mundo regularmente constituido y un alma aislada, que quiere crear ese orden regular por la caballería, cuando ésta sólo podría trastornarlo. Pero, a pesar de esta divertida aberración, Cervantes ha hecho de su héroe un carácter naturalmente noble, dotado de una multitud de buenas cualidades del espíritu y del corazón, que le hacen ingenuamente interesante. Don Quijote está, a pesar de su locura, perfectamente seguro de sí mismo y de su fin; o, más bien, su locura consiste en esta convicción profunda y en su idea fija. Sin esta espontánea seguridad no sería un personaje realmente cómico. Esta imperturbable seguridad en la verdad de sus opiniones es todavía realzada de modo absolutamente grande y acertado por los más hermosos rasgos de carácter. No por eso deja de ser toda la obra una perpetua burla de la caballería. En toda ella reina una verdadera ironía, mientras que en el Ariosto el relato de todas esas aventuras es sólo una burla frívola. Pero, por otra parte, la historia de Don Quijote es sólo la trama en que se entremezcla toda una serie de novelas verdaderamente románticas. La institución que la novela destruye por el ridículo, conserva en ellas su valor y su importancia.

\section{Balaam y su asna ${ }^{26}$ \\ W. H. Auden (1907-1973)}

La más grande de las parejas de espíritu y naturaleza y la más ortodoxa es, por supuesto, Don Quijote y Sancho Panza. A diferencia de Próspero y Calibán, su relación es armoniosa y feliz y, a diferencia de Tamino y Papageno, es dialéctica: se afectan entre sí. Además, tanto ellos como su relación son cómicos; Don Quijote está cómicamente loco, Sancho está cómicamente cuerdo, y cada uno encuentra al otro una adorable figura de diversión, una fuente sin fin de diversión. Es esta comedia omnipresente la que hace al libro ortodoxo; preséntese la relación como trágica y la conclusión es maniquea, preséntese seriamente a ambos o a uno de los personajes y la conclusión es pagana o pelagiana. El hombre que toma

${ }^{26}$ Fragmento de "Balaam y su asna", tomado de La mano del teñidor. Ensayos sobre cultura, poesía, teatro, música y ópera, Adriana Hidalgo editora (Buenos Aires, 1999). 
en serio la orden de Cristo de coger su cruz y seguirlo debe, si es serio, verse como una figura cómica, pues él no es el Cristo, es sólo un hombre como el resto; pero él cree que la orden "Sé perfecto" está en realidad dirigida a él.

... La falta de ilusiones de Don Quijote sobre su propio poder es signo de que su locura no es sólo mundana sino santa, un abandono del mundo, pero sin Sancho no sería cristiana. Para que sea cristiana él debe tener un prójimo, alguien aparte de sí mismo, sobre quien no tenga ilusiones pero que ame como él. Sin Sancho, Don Quijote estaría sin prójimos, y la clase de religión implicada sería una en la cual el amor de Dios no fuera sólo posible sin el amor del prójimo sino incompatible con él.

\author{
IX. Disquisición en el insomnio ${ }^{27}$ \\ Carlos Drummond de Andrade (1902-1987) \\ ¿Qué es locura: ser caballero andante o seguirlo como escudero? \\ ¿De él o yo, quién es loco verdadero? \\ ¿El que, despierto, sueña insanamente? \\ ¿El que, aunque esté vendado, \\ sigue el sueño y ve lo real \\ de un loco por las brujas embrujado? \\ Heme, tal vez, único demente \\ y sabiéndome tal, fuera de quicio, \\ soy —insensato - un loco de juicio.
}

${ }^{27}$ Tomado de Don Qixote (México: Secretaría de Educación Pública, Dirección General de Publicaciones y Medios, 1985). 


\section{DULCINEA: EL IDEAL Y LA IMAGINACIÓN}

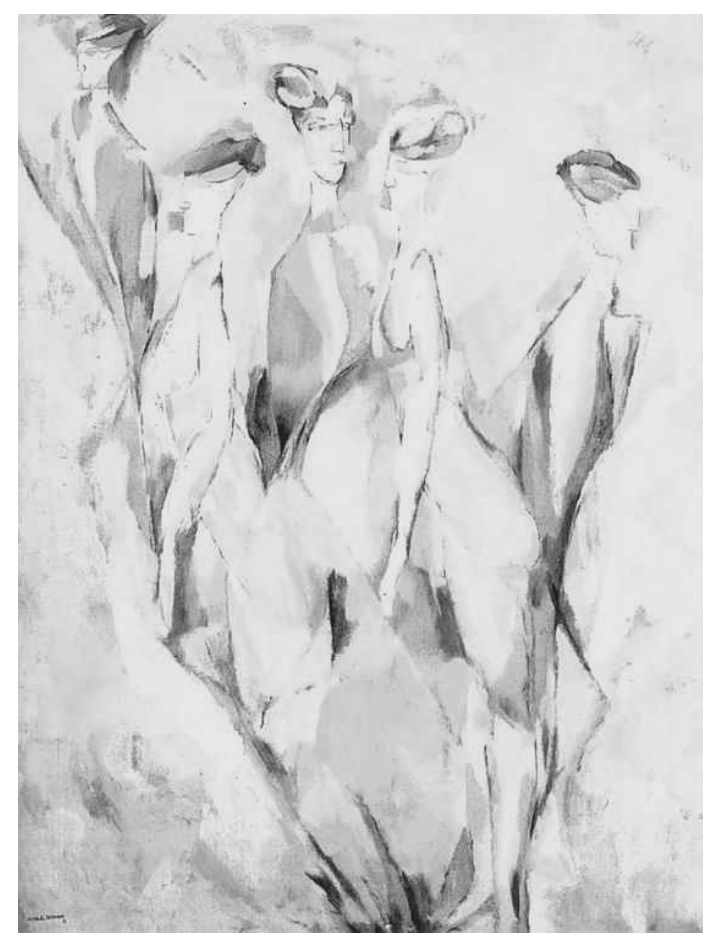

Marcel Duchamp, Dulcinea, 1911.

"—¿Pues qué se ha de hacer de la firma? — dijo Sancho.

-Nunca las cartas de Amadís se firman — respondió don Quijote.

-Está bien - respondió Sancho-; pero la libranza forzosamente se ha de firmar, y ésa, si se traslada, dirán que la firma es falsa y quedáreme sin pollinos.

- La libranza irá en el mesmo librillo firmada; que en viéndola mi sobrina, no pondrá dificultad en cumplilla. Y en lo que toca a la carta de amores, pondrás por firma: 'Vuestro hasta la muerte, el Caballero de la Triste Figura.' Y hará poco al caso que vaya de mano ajena, porque, a lo que yo me sé acordar, Dulcinea no sabe escribir ni leer, y en toda su vida ha visto letra mía ni carta mía, porque mis amores y los suyos han sido siempre platónicos, sin exten- 
derse a más que a un honesto mirar. $\mathrm{Y}$ aun esto tan de cuando en cuando, que osaré jurar con verdad que en doce años que ha que la quiero más que a la lumbre destos ojos que han de comer la tierra, no la he visto cuatro veces, y aun podrá ser que destas cuatro veces no hubiese ella echado de ver la una que la miraba; tal es el recato y encerramiento con que su padre, Lorenzo Corchuelo, y su madre, Aldonza Nogales, la han criado.

— iTa, ta! —dijo Sancho—. ¿Que la hija de Lorenzo Corchuelo es la señora Dulcinea del Toboso, llamada por otro nombre Aldonza Lorenzo?

—Ésa es —dijo don Quijote—, y es la que merece ser señora de todo el universo.

- Bien la conozco - dijo Sancho-, y sé decir que tira tan bien una barra como el más forzudo zagal de todo el pueblo. ¡Vive el Dador, que es moza de chapa, hecha y derecha y de pelo en pecho, y que puede sacar la barba del lodo a cualquier caballero andante, o por andar, que la tuviere por señora! ¡Oh hideputa, qué rejo que tiene, y qué voz! Sé decir que se puso un día encima del campanario del aldea a llamar unos zagales suyos que andaban en un barbecho de su padre, y aunque estaban de allí más de media legua, así la oyeron como si estuvieran al pie de la torre; y lo mejor que tiene es que no es nada melindrosa, porque tiene mucho de cortesana: con todos se burla, y de todo hace mueca y donaire. Ahora digo, señor Caballero de la Triste Figura, que no solamente puede y debe vuestra merced hacer locuras por ella, sino que, con justo título, puede desesperarse y ahorcarse, que nadie habrá que lo sepa que no diga que hizo demasiado de bien, puesto que le lleve el diablo; y querría ya verme en camino, sólo por vella; que ha muchos días que no la veo, y debe de estar ya trocada, porque gasta mucho la faz de las mujeres andar siempre al campo, al sol y al aire. Y confieso a vuestra merced una verdad, señor don Quijote: que hasta aquí he estado en una grande ignorancia; que pensaba bien y fielmente que la señora Dulcinea debía de ser alguna princesa de quien vuestra merced estaba enamorado, o alguna persona tal, que mereciese los ricos presentes que vuestra merced le ha enviado, así el del vizcaíno como el de los galeotes, y otros muchos que deben ser, según deben de ser muchas las victorias que vuestra merced ha ganado y ganó en el tiempo que yo aún no era su escudero; pero, bien considerado, ¿qué se le ha de dar a la señora Aldonza 
Lorenzo, digo, a la señora Dulcinea del Toboso, de que se la vayan a hincar de rodillas delante della los vencidos que vuestra merced envía y ha de enviar? Porque podría ser que al tiempo que ellos llegasen estuviese ella rastrillando lino, o trillando en las eras, y ellos se corriesen de verla, y ella se riese y enfadase del presente.

-Ya te tengo dicho antes de agora muchas veces, Sancho — dijo don Quijote-, que eres muy grande hablador, y que, aunque de ingenio boto, muchas veces despuntas de agudo; mas, para que veas cuán necio eres tú y cuán discreto soy yo, quiero que me oyas un breve cuento. Has de saber que una viuda hermosa, moza, libre y rica, y, sobre todo, desenfadada, se enamoró de un mozo motilón, rollizo y de buen tono; alcanzólo a saber su mayor, y un día dijo a la buena viuda, por vía de fraternal reprensión: 'Maravillado estoy, señora, y no sin mucha causa, de que una mujer tan principal, tan hermosa y tan rica como vuestra merced, se haya enamorado de un hombre tan soez, tan bajo y tan idiota como fulano, habiendo en esta casa tantos maestros, tantos presentados y tantos teólogos, en quien vuestra merced pudiera escoger como entre peras, y decir: Éste quiero, aquéste no quiero'. Mas ella le respondió con mucho donaire y desenvoltura: 'Vuestra merced, señor mío, está muy engañado, y piensa muy a lo antiguo, si piensa que yo he escogido mal en fulano, por idiota que le parece; pues para lo que yo le quiero, tanta filosofía sabe, y más, que Aristóteles.' Así que, Sancho, por lo que yo quiero a Dulcinea del Toboso, tanto vale como la más alta princesa de la tierra. Sí, que no todos los poetas que alaban damas, debajo de un nombre que ellos a su albedrío les ponen, es verdad que las tienen. ¿Piensas tú que las Amariles, las Filis, las Silvias, las Dianas, las Galateas, las Alidas y otras tales de que, los libros, los romances, las tiendas de los barberos, los teatros de las comedias, están llenos, fueron verdaderamente damas de carne y hueso, y de aquellos que las celebran y celebraron? No, por cierto, sino que las más se las fingen por dar subjeto a sus versos, y porque los tengan por enamorados y por hombres que tienen valor para serlo. Y así, bástame a mí pensar y creer que la buena de Aldonza Lorenzo es hermosa y honesta; y en lo del linaje importa poco, que no han de ir a hacer la información dél para darle algún hábito, y yo me hago cuenta que es la más alta princesa del mundo. Porque 
has de saber, Sancho, si no lo sabes, que dos cosas solas incitan a amar más que otras, que son la mucha hermosura y la buena fama, y estas dos cosas se hallan consumadamente en Dulcinea, porque en ser hermosa ninguna le iguala, y en la buena fama, pocas le llegan. Y para concluir con todo, yo imagino que todo lo que digo es así, sin que sobre ni falte nada, y píntola en mi imaginación como la deseo, así en la belleza como en la principalidad, y ni la llega Elena, ni la alcanza Lucrecia, ni otra alguna de las famosas mujeres de las edades pretéritas, griega, bárbara o latina. Y diga cada uno lo que quisiere; que si por esto fuere reprendido de los ignorantes, no seré castigado de los rigurosos.

(Primera Parte, Cap. XXV, pp. 241-244.)

\section{$* * *$}

En el capítulo XXV de la Primera Parte, don Quijote se ve forzado a reconocer que Dulcinea no es nada más ni nada menos que Aldonza Lorenzo, una moza de campo. El choque para Sancho, que la creía verdaderamente una princesa, va a ser grande. El fragmento aquí transcrito muestra la correspondencia entre realidad e ideal, destinados ambos al contraste en algún momento por la necesidad de expandir su mundo. Don Quijote necesita que Sancho crea, y así, la conciencia de una realidad bastante soez es salvada por la imaginación. Fue el capítulo preferido por todo el Romanticismo. Al deseo poco le importa; el deseo, como dijera Nietzsche, se da a sí mismo. El mundo es voluntad. Dulcinea, como cierra el poema de Paz "fue mujer, y ya es idea". También estas relaciones que muestran la creación de un ideal, desnudan la contracara y la figura de Dulcinea: la mujer que todos soñamos y pintamos en nuestra imaginación, es otra.

Las constantes intermitencias con nuestros Otros creados fue tema en Borges. La línea del sueño en los niveles de ficción ha invertido la ficcionalización, y algunos personajes son hijos de personajes, más reales que los reales, otros se pierden en el círculo, entre espejos que agregan al mundo imágenes y laberintos sin oriente. Sancho crea a don Quijote, Dulcinea crea a don Quijote, don Quijote tiene descendientes. 
La Dulcinea de Marcel Duchamp ${ }^{28}$

Octavio Paz (1914-1998)

A Eulalio Ferrer

- Metafisica estáis.

-Hago striptease.

Ardua pero plausible, la pintura

cambia la tela blanca en pardo llano

y en Dulcinea al polvo castellano

torbellino resuelto en escultura.

Transeúnte de París, en su figura

-molino de ficciones, inhumano

rigor y geometría - Eros tirano

desnuda en cinco chorros su estatura.

Mujer en rotación que se disgrega

y es surtidos de sesgos y reflejos:

mientras más se desviste más se niega.

La mente es una cámara de espejos;

invisible en el cuadro, Dulcinea

perdura: fue mujer y ya es idea.

\section{La abadía de las pesadillas ${ }^{29}$}

Thomas Love Peacock (1785-1866)

Mr. Hillary: Todas estas anécdotas pueden tener solución por principios psicológicos. Es más fácil para un soldado, un filósofo o hasta para un santo asustarse de su propia sombra que para un muerto salir de su tumba. Los médicos han escrito sobre mil ejemplos singulares de la fuerza de la imaginación. Personas de temperamento débil, nervioso o melancólico, extenuadas por la fiebre, el trabajo o una débil alimentación, conjuran con rapidez, en el círculo mágico de su propia fantasía, espectros, górgonas, quimeras y todos los objetos de su odio y de su amor. La mayoría de nosotros somos como Don Quijote, para quien un molino es un gigante, y Dulcinea, una magnífica princesa: todos más o menos víctimas de nuestra propia ima-

${ }^{28}$ Tomado del volumen de poesía Árbol adentro (Barcelona: Edit. Seix-Barral, 1987).

${ }^{29}$ Tomado de la "Mansión de las pesadillas", capítulo XII, de La abadía de las pesadillas. 
ginación, a pesar de que no todos lleguemos tan lejos como para ver fantasmas, como para imaginarnos seres de ultratumba, donde sólo hay ollas y teteras.

\section{Teoría de Dulcinea ${ }^{30}$ \\ Juan José Arreola (1918-2001)}

En un lugar solitario cuyo nombre no viene al caso, hubo un hombre que se pasó la vida eludiendo a la mujer concreta. Prefirió el goce manual de la lectura, y se congratulaba eficazmente cada vez que un caballero andante embestía a fondo uno de esos vagos fantasmas femeninos, hechos de virtudes y faldas superpuestas, que aguardan al héroe después de cuatrocientas páginas de hazañas, embustes y despropósitos.

En el umbral de la vejez, una mujer de carne y hueso puso sitio al anacoreta en su cueva. Con cualquier pretexto entraba al aposento y lo invadía con un fuerte aroma de sudor y de lana, de joven mujer campesina recalentada por el sol.

El caballero perdió la cabeza, pero lejos de atrapar a la que tenía enfrente, se echó en pos a través de páginas y páginas, de un pomposo engendro de fantasía. Caminó muchas leguas, alanceó corderos y molinos, desbarbó unas cuantas encinas y dio tres o cuatro zapatetas en el aire. Al volver de la búsqueda infructuosa, la muerte le aguardaba en la puerta de su casa. Sólo tuvo tiempo para dictar un testamento cavernoso, desde el fondo de su alma reseca. Pero un rostro polvoriento de pastora se lavó con lágrimas verdaderas, y tuvo un destello inútil ante la tumba del caballero demente.

\section{Dulcinea del Toboso ${ }^{31}$}

Marco Denevi (1922-1998)

Leyó tantas novelas que terminó perdiendo la razón. Se hacía llamar Dulcinea del Toboso (en realidad se llamaba Aldonza Lorenzo), se creía

${ }^{30}$ Texto completo del relato, tomado de Confabulario total (México: Fondo de Cultura Económica, $3^{\mathrm{a}}$ edición, 1962).

${ }^{31}$ Texto completo, tomado de Obras completas (Buenos Aires: Ediciones Corregidor, 1980). 
princesa (era hija de aldeanos), se imaginaba joven y hermosa (tenía cuarenta años y la cara picada de viruelas). Finalmente se inventó un enamorado al que le dio el nombre de don Quijote de la Mancha. Decía que don Quijote había partido hacia remotos reinos en busca de aventuras y peligros, tanto como para hacer méritos y, a la vuelta, poder casarse con una dama de tanto copete como ella. Se pasaba todo el tiempo asomada a la ventana esperando el regreso del inexistente caballero. Alonso Quijano, un pobre diablo que la amaba, ideó hacerse pasar por don Quijote. Vistió una vieja armadura, montó en su rocín y salió a los caminos a repetir las hazañas que Dulcinea atribuía a su galán. Cuando, seguro del éxito de su estratagema, volvió al Toboso, Dulcinea había muerto.

\section{Sueña Alonso Quijano ${ }^{32}$ \\ Jorge Luis Borges (1899-1986) \\ El hombre se despierta de un incierto sueño de alfanjes y de campo llano y se toca la barba con la mano y se pregunta si está herido o muerto. ¿No lo perseguirán los hechiceros que han jurado su mal bajo la luna? Nada. Apenas el frío. Apenas una dolencia de sus años postrimeros. El hidalgo fue un sueño de Cervantes y don Quijote un sueño del hidalgo. El doble sueño los confunde y algo está pasando que pasó mucho antes. Quijano duerme y sueña. Una batalla: los mares de Lepanto y la metralla.}

\footnotetext{
${ }^{32}$ Del poemario La rosa profunda, tomado de Obra poética, 3 (Madrid: Edito-
} rial Alianza, 1998). 


\section{ESPAÑA: LA RAZA Y EL DESTINO}

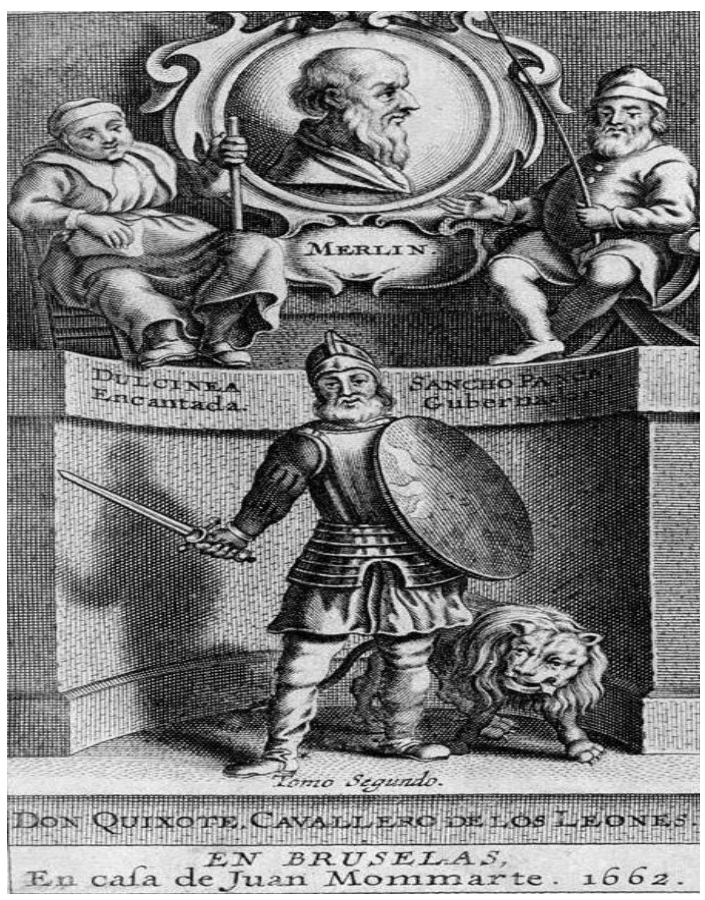

Bruselas, 1662 .

"Halláronse presentes a la plática la sobrina y ama, y no se hartaban de dar gracias a Dios de ver a su señor con tan buen entendimiento; pero el cura, mudando el propósito primero, que era de no tocarle en cosa de caballerías, quiso hacer de todo en todo experiencia si la sanidad de don Quijote era falsa o verdadera, y así, de lance en lance, vino a contar algunas nuevas que habían venido de la corte, y, entre otras, dijo que se tenía por cierto que el Turco bajaba con una poderosa armada, y que no se sabía su designio, ni adónde había de descargar tan gran nublado; y con este temor, con que casi cada año nos toca arma, estaba puesta en ella toda la cristiandad, y Su Majestad había hecho proveer las costas de Nápoles y Sicilia y la isla de Malta. A esto respondió don Quijote: 
- Su Majestad ha hecho como prudentísimo guerrero en proveer sus estados con tiempo, porque no le halle desapercebido el enemigo; pero si se tomara mi consejo, aconsejárale yo que usara de una prevención, de la cual Su Majestad la hora de agora debe de estar muy ajeno de pensar en ella.

Apenas oyó esto el cura, cuando dijo entre sí: —Dios te tenga de su mano, pobre don Quijote; que me parece que te despeñas de la alta cumbre de tu locura hasta el profundo abismo de tu simplicidad!

Mas el barbero, que ya había dado en el mesmo pensamiento que el cura, preguntó a don Quijote cuál era la advertencia de la prevención que decía era bien se hiciese; quizá podría ser tal que se pusiese en la lista de los muchos advertimientos impertinentes que se suelen dar a los príncipes.

—El mío, señor rapador — dijo don Quijote—, no será impertinente, sino perteneciente.

-No lo digo por tanto — replicó el barbero—, sino porque tiene mostrado la experiencia que todos o los más arbitrios que se dan a Su Majestad, o son imposibles, o disparatados, o en daño del rey o del reino.

—Pues el mío — respondió don Quijote- ni es imposible ni disparatado, sino el más fácil, el más justo y el más mañero y breve que puede caber en pensamiento de arbitrante alguno.

- Ya tarda en decirle vuestra merced, señor don Quijote - dijo el cura.

-No querría — dijo don Quijote- que le dijese yo aquí agora, y amaneciese mañana en los oídos de los señores consejeros, y se llevase otro las gracias y el premio de mi trabajo.

—Por mí — dijo el barbero—, doy la palabra, para aquí y para delante de Dios, de no decir lo que vuesa merced dijere a rey ni a roque, ni a hombre terrenal, juramento que aprendí del romance del cura que en el prefacio avisó al rey del ladrón que le había robado las cien doblas y la su mula la andariega.

—No sé historias — dijo don Quijote—; pero sé que es bueno ese juramento, en fe de que sé que es hombre de bien el señor barbero. 
- Cuando no lo fuera - dijo el cura-, yo le abono y salgo por él, que en este caso no hablará más que un mudo, so pena de pagar lo juzgado y sentenciado.

-Y a vuesa merced, ¿quién le fía, señor cura? — dijo don Quijote.

-Mi profesión — respondió el cura-, que es de guardar secreto.

- iCuerpo de tal! —dijo a esta sazón don Quijote-. ¿Hay más sino mandar Su Majestad por público pregón que se junten en la corte para un día señalado todos los caballeros andantes que vagan por España, que aunque no viniesen sino media docena, tal podría venir entre ellos, que sólo bastase a destruir toda la potestad del Turco? Esténme vuesas mercedes atentos y vayan conmigo. ¿Por ventura es cosa nueva deshacer un solo caballero andante un ejército de docientos mil hombres, como si todos juntos tuvieran una sola garganta, o fueran hechos de alfeñique? Si no, díganme: ¿cuántas historias están llenas destas maravillas? ¡Había, en hora mala para mí, que no quiero decir para otro, de vivir hoy el famoso don Belianís, o alguno de los del innumerable linaje de Amadís de Gaula; que si alguno déstos hoy viviera y con el Turco se afrontara, a fe que no le arrendara la ganancia! Pero Dios mirará por su pueblo, y deparará alguno que, si no tan bravo como los pasados andantes caballeros, a lo menos no te será inferior en el ánimo; y Dios me entiende, y no digo más."

(Segunda Parte, Cap. I, pp. 550-552.)

España se ha perdido en su obsesión por sí misma, en un ideal raro, equívoco, convirtiéndose en un resbaladizo objeto de autorreflexión. Los españoles se han agotado en cavilaciones sobre su naturaleza contradictoria, para terminar rumiando sobre la muerte; se han perdido por exceso de profundidad. Así, meditan sobre el símbolo, rastreando en la ambigüedad del texto y del personaje cervantino las huellas de una decadencia de tres siglos. Cioran echa algunas luces al respecto, hondo en su percepción del hidalgo como figura representativa de una paradoja irreducible a formulaciones lógicas. Así, Kundera fustiga a quienes perseveran en buscar una posición moral y no una interrogante en el fondo del texto, pues el mundo de Cervantes es una ambigüedad, un montón de verdades relativas, de frases 
diversas y contradictorias, como las de los diálogos entre don Quijote y su escudero, que para Machado son, en cambio, fiel reflejo del alma española: de su forma y su contenido.

\section{Pequeña teoría del destino ${ }^{33}$}

Émile M. Cioran (1911-1995)

Ciertos pueblos, como el ruso y el español, están tan obsesionados por sí mismos que se erigen en único problema: su desarrollo, en todo punto singular, les obliga a replegarse sobre su serie de anomalías, sobre el milagro o insignificancia de su suerte ... España se inclina sobre sí misma por razones opuestas [a Rusia]. Tuvo también comienzos fulgurantes, pero están muy lejanos. Llegada demasiado pronto, trastornó el mundo y se dejó caer: esta caída se me reveló un día. Fue en Valladolid, en la Casa de Cervantes. Una vieja de apariencia vulgar, contemplaba el retrato de Felipe III; "Un loco", le dije. Ella se volvió hacia mí: "Con él comenzó nuestra decadencia”. Yo estaba en el corazón del problema. “¡Nuestra decadencia!”. Así que, pensé, la decadencia es, en España, un concepto corriente, nacional, un cliché, una divisa oficial. La nación que, en el siglo XVI, ofrecía al mundo un espectáculo de magnificencia y de locura, hela ahí reducida a codificar su abotargamiento. Si hubieran tenido tiempo, sin duda los últimos romanos no hubieran actuado de otra forma; no pudieron remachar su fin: los bárbaros se cernían ya sobre ellos. Más afortunados, los españoles tuvieron plazo suficiente (itres siglos!) para pensar en sus miserias y empaparse de ellas. Charlatanes por desesperación, improvisadores de ilusiones, viven en una especie de acritud cantante, de trágica falta de seriedad, que les salva de la vulgaridad de la felicidad y del éxito. Aunque cambiasen un día sus antiguas manías por otras más modernas, seguirían, empero, marcados por una ausencia tan larga. Incapaces de acoplarse al ritmo de la "civilización", clericoidales o anarquistas, no podrían renunciar a su inactualidad. ¿Cómo van a alcanzar a las otras naciones, cómo se van a poner al día, si han agotado lo mejor de sí mismos en rumiar sobre la muerte, en embadurnarse con ella, en convertirla en experiencia visceral? Retrocediendo sin cesar hacia lo esencial, se han perdido por exceso de profundidad. La idea de decadencia no les preocuparía tanto si no tradujese en términos de historia

\footnotetext{
33 Tomado de La tentación de existir (Madrid: Taurus, 2000).
} 
su gran debilidad por la nada, su obsesión por el esqueleto. No es nada asombroso que, para cada uno de ellos, el país sea su problema. Leyendo a Ganivet, Unamuno u Ortega, uno advierte que, para ellos, España es una paradoja que les atañe íntimamente y que no logran reducir a una fórmula racional. Vuelven siempre sobre ella, fascinados por la atracción de lo insoluble que representa. No pudiendo resolverla por el análisis, meditan sobre Don Quijote, en el que la paradoja es todavía más insoluble, porque es símbolo. Uno no se imagina a un Valéry o a un Proust meditando sobre Francia para descubrirse a sí mismos: país realizado, sin rupturas graves que soliciten inquietud, país no-trágico, no es un caso: al haber triunfado, al haber cumplido su suerte, ¿cómo podría ser aún "interesante"?

\section{La desprestigiada herencia de Cervantes $^{34}$}

\section{Milan Kundera (1929)}

Comprender con Cervantes el mundo como ambigüedad, tener que afrontar, no una única verdad absoluta, sino un montón de verdades relativas que se contradicen (verdades incorporadas a los egos imaginarios llamados personajes), poseer como única certeza la sabiduría de lo incierto, exige una fuerza igualmente notable.

¿Qué quiere decir la gran novela de Cervantes? Hay una abundante literatura a este respecto. Algunos pretenden ver en esta novela la crítica racionalista del idealismo confuso de don Quijote. Otros ven la exaltación de este mismo idealismo. Ambas interpretaciones son erróneas porque quieren encontrar en el fondo de la novela no un interrogante, sino una posición moral.

\section{Elogio a Cervantes ${ }^{35}$ \\ José Carlos Mariátegui (1894-1930)}

Una lengua, una historia, una casta bravía concibieron los siglos en un sueño ancestral y la raza española fue como una ironía

\footnotetext{
${ }^{34}$ Fragmento del ensayo "La desprestigiada herencia de Cervantes", tomado de El arte de la novela (Madrid: Editorial Alfaguara, 1986)

${ }^{35}$ Fragmento de "Elogio a Cervantes" [1916], tomado de Escritos juveniles. La edad de piedra, Tomo I (Lima: Empresa editora Amauta, 1916).
} 
de los siglos obsesos por un raro ideal. Gesta de aventureros, hijodalga porfía por alguna quimera, cruzada medioeval y más tarde los libros de Caballería forjando la locura del hidalgo inmortal. Cervantes tuvo para su tristeza imprecisa el antifaz de seda de una amarga sonrisa y la heroica epopeya de La Mancha escribió, pues fue porque este símbolo magnífico existiera y un libro de Cervantes al mundo le dijera que el sueño de los siglos una raza creó.

\section{Las meditaciones del Quijote de José Ortega y Gasset ${ }^{36}$}

Antonio Machado (1875-1939)

Para mí, el Quijote es, en primer término, un libro español; en segundo término, un problema apenas planteado o, si queréis, un misterio. Fue Cervantes, ante todo, un gran pescador de lenguaje, de lenguaje vivo, hablado y escrito; a grandes redadas aprisionó Cervantes enorme cantidad de lengua hecha, es decir, que contenía ya una expresión acabada de la mentalidad de un pueblo. El material con que Cervantes trabaja, el elemento simple de su obra, no es el vocablo, sino el refrán, el proverbio, la frase hecha, el donaire, la anécdota, el modismo, el lugar corriente, la lengua popular, en suma, incluyendo en ella la cultura media de Universidades y Seminarios. Con dificultad encontraréis en el Quijote una ocurrencia original, un pensamiento que lleve la mella del alma de su autor. A primera vista parece que Cervantes se ahorra el trabajo de pensar. Deja que la lengua de los arrieros y de los bachilleres, de los pastores y de los soldados, de los golillas, de los buhoneros y vagabundos piensen por él. Desde este punto de vista, el Quijote viene a ser como la enciclopedia del sentido común español, contenida en la lengua española de principios del siglo XVII. No es la cazurrería de Sancho ni la locura de Don Quijote lo que nos asombra y abruma en la lectura del libro inmortal, sino la estupenda discreción de ambos. Con esta primera y superficial visión del Quijote bien se puede decir que la característica de Cervantes es el buen sentido. Don Quijote y Sancho son dos encantadores charlatanes, que derrochan conceptos como el pródigo su riqueza y

${ }^{36}$ Fragmento de "Las meditaciones del Quijote de José Ortega y Gasset", tomado de Prosas dispersas, edición anotada de Jordi Doménech (Madrid: Editorial Páginas de Espuma, 2001). 
se recrean en la fácil sabiduría que fluye de sus labios. Hay cierta elocuencia en ambos, cierta complacencia en la verbosidad que revela la falta de esfuerzo mental, la ausencia de reflexión, la alegría de disparar con pólvora ajena, si se me permite la frase. Jamás descubriréis ni en Don Quijote ni en Sancho el esfuerzo para calcar fielmente la línea sinuosa del propio sentimiento. ¿Para qué este esfuerzo? A una anécdota se contesta con otra, a un concepto con el contrario, contra dos refranes hay siempre a mano otros dos, una sentencia se refuta con otra. Cervantes es, en este primer plano de su obra, la antítesis de Teresa de Ávila. En la Santa, lo rico no es el lenguaje, sino lo que pretende expresarse con él; la materia con que labora Teresa es su propia alma; la materia cervantina es el alma española, objetivada ya en la lengua de su siglo. Es en vano buscar a Cervantes, rebuscando en su léxico, con un criterio filológico o meramente lógico y gramatical. Cervantes no aparece entonces por ninguna parte $-\mathrm{y}$ esto ha creado el equívoco cervantino-, sino la mentalidad omnibus de la España de su tiempo.

Pero la lengua hablada en España, con su castizo contenido mental, es la materia en que Cervantes ha trabajado, no su obra; como una estatua no es la piedra en la cual se la ha esculpido, sino las líneas ideales que en el mármol fue trazando un cincel. Hombres muy sutiles - Gracián, por ejemplo- desdeñaron el Quijote porque, sin duda, no vieron la obra, sino su materia bruta. No es, ciertamente, en la vida de Cervantes, en sus andanzas de pretendiente despreciado, de soldado sin fortuna o de mísero alcabalero, donde es preciso buscar el secreto del Quijote; pero no es tampoco en su libro, entendiendo por tal el abundante caudal de castizos lugares comunes de que está formado. El Quijote es preciso verlo, abarcarlo con una visión mental, representárnoslo, para darnos cuenta de la obra cervantina, y formularnos esta pregunta: ¿Qué hizo Cervantes con la lengua española en ese monumento único que se llama el Quijote? No se pregunta lo que haya pretendido hacer. La obra de un poeta desborda y supera infinitamente su propósito. Cervantes, acaso, pretendió no más que poner en ridículo los libros de caballerías, empresa al alcance de un Pérez Zúñiga de su tiempo; propósito trivialísimo muy propio de un ingenio de tercer orden, que nos da, tal vez, la medida del valor en que Cervantes se tasaba a sí mismo al comenzar su obra. Cierto que la mezquindad del propósito inicial contribuirá a mantener el equívoco cervantino. Pero aquí se pregunta por lo que hizo Cervantes en su libro, y esta interrogación no contestada forma parte, a su vez, de la inmortalidad del Quijote. 
VII. LECTORES: CORRECTORES Y LEGISLADORES

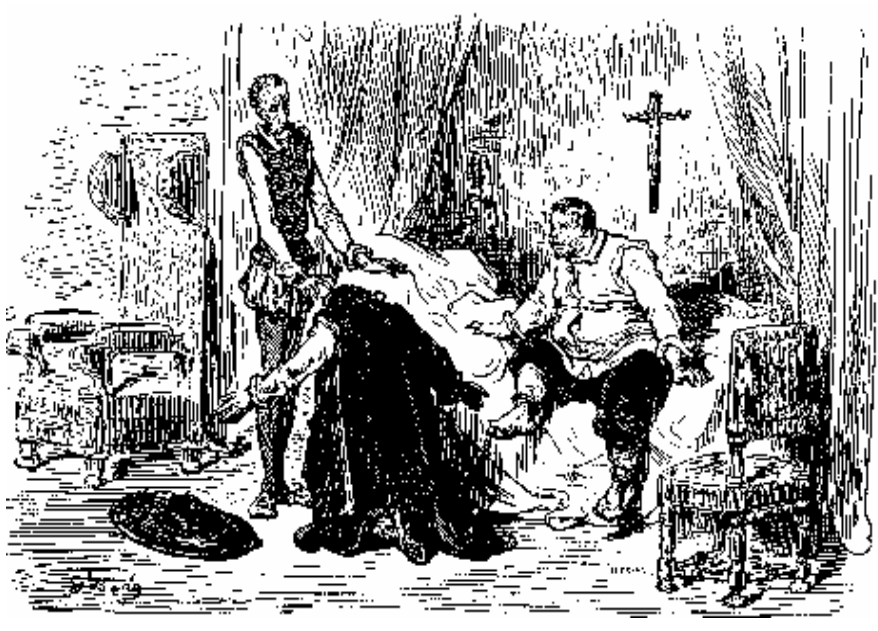

G. Doré.

"-Una de las tachas que ponen a la tal historia — dijo el bachiller- es que su autor puso en ella una novela intitulada El Curioso impertinente; no por mala ni por mal razonada, sino por no ser de aquel lugar, ni tiene que ver con la historia de su merced del señor don Quijote.

-Yo apostaré — replicó Sancho- que ha mezclado el hi de perro berzas con capachos.

- Ahora digo — dijo don Quijote- que no ha sido sabio el autor de mi historia, sino algún ignorante hablador, que a tiento y sin algún discurso se puso a escribirla, salga lo que saliere, como hacía Orbaneja, el pintor de Úbeda, al cual, preguntándole qué pintaba, respondió: 'Lo que saliere.' Tal vez pintaba un gallo, de tal suerte y tan mal parecido, que era menester que con letras góticas escribiese junto a él: 'Éste es gallo.' Y así debe ser de mi historia, que tendrá necesidad de comento para entenderla.

-Eso no - respondió Sansón-, porque es tan clara que no hay cosa que dificultar en ella: los niños la manosean, los mozos la leen, los hombres la entienden y los viejos la celebran; $y$, finalmente, es tan trillada y tan leída y tan sabida de todo género de gentes que apenas han visto algún rocín flaco, cuando dicen: 'Allí va Rocinante.' Y los que más se han dado a su letura son los pajes: no hay 
antecámara de señor donde no se halle un Don Quijote: unos le toman si otros le dejan; éstos le embisten y aquéllos le piden. Finalmente, la tal historia es del más gustoso y menos perjudicial entretenimiento que hasta agora se haya visto, porque en toda ella no se descubre, ni por semejas, una palabra deshonesta ni un pensamiento menos que católico.

- A escribir de otra suerte — dijo don Quijote-, no fuera escribir verdades, sino mentiras, y los historiadores que de mentiras se valen habían de ser quemados, como los que hacen moneda falsa; y no sé yo qué le movió al autor a valerse de novelas y cuentos ajenos, habiendo tanto que escribir en los míos: sin duda se debió de atener al refrán: 'De paja y de heno...', etcétera.”

(Segunda Parte, Cap. III, pp. 571-572.)

El rol del lector en torno a una obra como el Quijote no solamente completa el proceso de la creación literaria: le da sentido. Las constantes apelaciones al lector que lleva a cabo el narrador, son mucho más que un simple recurso estilístico que busca generar cierta complicidad entre ambos, éste (junto con otros recursos tales como la proliferación de "autores" en la obra que, para Riley, actúan como lectores críticos de la misma) busca endosarle al lector una responsabilidad para nada menor: darle sentido a la aventura quijotesca, produciendo una multiplicidad de posibilidades de interpretación que le proporcionan al texto una ambigüedad que más de un crítico ha recalcado (Durán, Allen, Kundera). La reacción más común es la identificación con el personaje, que Borges, a través de su Pierre Menard, lector obsesivo de Cervantes, extrema. En el relato, autor y obra constituyen una totalidad indisoluble. Para Fuentes, por otra parte, la obra en su totalidad es una crítica a las convenciones implícitas en la lectura, así el barroquismo, los excesos y la satirización de las formas narrativas en boga que se practican en las historias intercaladas, buscarían transformar de raíz el acto de lectura, asumiendo que es a partir de éste que se concreta la experiencia literaria, marcando así su preeminencia. Para Nietzsche, Cervantes mostraría su desprecio por el género humano, subestimando a sus lectores. La sátira generalizada que es el Quijote produciría un efecto equiparador entre éstos: hasta los necios se sentirían sabios, y ninguno de ellos podría percibir la crueldad que trasunta la novela. Todos estarían demasiado ocupados reconociendo a sus semejantes en los personajes satirizados como para ver la crueldad y el patetismo de las humillaciones que sufre el andante caballero. 


\section{Pierre Menard, autor del Quijote ${ }^{37}$}

Jorge Luis Borges (1899-1986)

Hasta aquí (sin otra omisión que unos vagos sonetos circunstanciales para el hospitalario, o ávido, álbum de madame Henri Bachelier) la obra visible de Menard, en su orden cronológico. Paso ahora a la otra: la subterránea, la interminablemente heroica, la impar. También, ¡ay de las posibilidades del hombre!, la inconclusa. Esa obra, tal vez la más significativa de nuestro tiempo, consta de los capítulos noveno y trigésimo octavo de la primera parte del Don Quijote y de un fragmento del capítulo veintidós. Yo sé que tal afirmación parece un dislate; justificar ese "dislate" es el objeto primordial de esta nota [2].

Dos textos de valor desigual inspiraron la empresa. Uno es aquel fragmento filológico de Novalis - el que lleva el número 2005 en la edición de Dresden - que esboza el tema de la total identificación con un autor determinado. Otro es uno de esos libros parasitarios que sitúan a Cristo en un bulevar, a Hamlet en la Cannebiére o a don Quijote en Wall Street. Como todo hombre de buen gusto, Menard abominaba de esos carnavales inútiles, sólo aptos decía para ocasionar el plebeyo placer del anacronismo o (lo que es peor) para embelesarnos con la idea primaria de que todas las épocas son iguales o de que son distintas. Más interesante, aunque de ejecución contradictoria y superficial, le parecía el famoso propósito de Daudet: conjugar en una figura, que es Tartarín, al Ingenioso Hidalgo y a su escudero... Quienes han insinuado que Menard dedicó su vida a escribir un Quijote contemporáneo, calumnian su clara memoria.

No quería componer otro Quijote — lo cual es fácil— sino el Quijote. Inútil agregar que no encaró nunca una trascripción mecánica del original; no se proponía copiarlo. Su admirable ambición era producir unas páginas que coincidieran palabra por palabra y línea por línea con las de Miguel de Cervantes.

"Mi propósito es meramente asombroso", me escribió el 30 de septiembre de 1934 desde Bayonne. "El término final de una demostración teológica o metafísica —el mundo externo, Dios, la causalidad, las formas universales - no es menos anterior y común que mi divulgada novela. La sola diferencia es que los filósofos publican en agradables volúmenes las etapas intermediarias de su labor y que yo he resuelto perderlas." En efecto, no queda un solo borrador que atestigüe ese trabajo de años.

${ }^{37}$ Fragmento de "Pierre Menard, autor del Quijote", tomado de Ficciones (Madrid: Alianza Editorial, 1997). 
El método inicial que imaginó era relativamente sencillo. Conocer bien el español, recuperar la fe católica, guerrear contra los moros o contra el turco, olvidar la historia de Europa entre los años de 1602 y de 1918, ser Miguel de Cervantes. Pierre Menard estudió ese procedimiento (sé que logró un manejo bastante fiel del español del siglo diecisiete) pero lo descartó por fácil. ¡Más bien por imposible! dirá el lector. De acuerdo, pero la empresa era de antemano imposible y de todos los medios imposibles para llevarla a término, éste era el menos interesante. Ser en el siglo veinte un novelista popular del siglo diecisiete le pareció una disminución. Ser, de alguna manera, Cervantes y llegar al Quijote le pareció menos arduo - por consiguiente, menos interesante - que seguir siendo Pierre Menard y llegar al Quijote, a través de las experiencias de Pierre Menard. (Esa convicción, dicho sea de paso, le hizo excluir el prólogo autobiográfico de la segunda parte del Don Quijote. Incluir ese prólogo hubiera sido crear otro personaje - Cervantes- pero también hubiera significado presentar el Quijote en función de ese personaje y no de Menard. Éste, naturalmente, se negó a esa facilidad.) "Mi empresa no es difícil, esencialmente" leo en otro lugar de la carta. "Me bastaría ser inmortal para llevarla a cabo."

\section{Cervantes o la crítica de la lectura ${ }^{38}$}

\section{Carlos Fuentes (1928)}

Resulta que ese pícaro, galeote convicto y falso titiritero, Ginés de Pasamonte, alias Ginesillo de Parapilla, alias Maese Pedro, está escribiendo un libro sobre su propia vida. ¿Está terminado el libro?, pregunta Don Quijote. Y Ginés le contesta: ¿Cómo va a estarlo, si mi vida aún no termina?

Ésta es la última pregunta de Cervantes: ¿quién escribe los libros y quién los lee? ¿Quién es el autor del Quijote? ¿Un tal Cervantes, más versado en desdichas que en versos, cuya Galatea ha leído el cura que hace el escrutinio de los libros de don Quijote? ¿Un tal de Saavedra, mencionado por el Cautivo con admiración, en razón de los hechos que cumplió y todo por alcanzar la libertad?

Cervantes, como don Quijote, es leído por los personajes de la novela Quijote, libro sin origen autoral y casi sin destino, agonizante apenas nace, reanimado por los papeles del historiador arábigo Cide Hamete Benengeli, que son vertidos al castellano por un anónimo traductor morisco y que serán objeto de la versión apócrifa de Avellaneda... Puntos suspensivos. El círculo de las lecturas se reinicia. Cervantes, autor de Borges; Borges, autor de Pierre Ménard; Pierre Ménard, autor del Quijote.

${ }^{38}$ Tomado del capítulo XI de Cervantes o la crítica de la lectura (Alcalá de Henares: Centro de Estudios Cervantinos, 1994). 
Cervantes deja abierto un libro donde el lector se sabe leído y el autor se sabe escrito y se dice que muere, en la misma fecha aunque no en el mismo día que William Shakespeare. Eduardo Lizalde me contaba ayer que Augusto Monterroso sostiene que ambos eran el mismo personaje, que las prisiones y deudas y combates de Cervantes fueron ficciones que le permitieron disfrazarse de Shakespeare y escribir su obra de teatro en Inglaterra, en tanto que el comediante Shakespeare, el hombre de las mil caras, el Lon Chaney isabelino, escribía el Quijote en España. Esa disparidad entre los días reales y la fecha ficticia de una muerte común permitió al espectro de Cervantes trasladarse a Londres a tiempo para volver a morir en el cuerpo de Shakespeare. No sé si se trata del mismo personaje, pues los calendarios en Inglaterra y España nunca han sido los mismos, ni en 1615 ni hoy.

\section{Cómo condensar a los clásicos ${ }^{39}$}

Ernest Hemingway (1899-1961)

Casi han acabado el trabajo de condensar a los clásicos. Se trata de un pequeño grupo de entusiastas condensadores, supuestamente subvencionados por Andrew Carnegie, que han trabajado durante los últimos cinco años para reducir la literatura mundial a bocados comestibles para consumición del agotado hombre de negocios.

Los miserables ha sido reducido a diez páginas. Parece que Don Quijote ocupa una columna y media. Las obras teatrales de Shakespeare no pasan de ochocientas palabras cada una. La Iliada y La Odisea cabrán en el texto de un componedor y medio cada una.

Es algo magnífico poner a los clásicos al alcance del hombre de negocios cansado o retirado, aunque estigmatice el intento de colegios y universidades de poner al hombre de negocios al alcance de los clásicos. Pero aún hay un modo más rápido de presentar el asunto a quienes han de correr mientras leen: reducir toda la literatura a titulares de prensa, seguidos de una pequeña nota que resuma el argumento.

Por ejemplo, El Quijote:

CABALLERO DEMENTE EN UNA LUCHA ESPECTRAL

Madrid, España (Agencia de Noticias Clásicas) (Especial). Se atribuye a histerismo de guerra la extraña conducta de don Quijote, un caballero local que ayer por la mañana fue arrestado mientras "combatía" con un molino. Quijote no supo dar una explicación de sus actos.

39 Tomado del artículo "Cómo condensar a los clásicos", publicado en The Toronto Star Weekly, 20 de agosto de 1921. 


\section{Fragmento inédito ${ }^{40}$}

Friedrich Nietzsche (1844-1900)

Los poetas, de acuerdo con su naturaleza, que es cabalmente una naturaleza de artista, es decir, de hombres raros y excepcionales, no ensalzan siempre lo que merece ser ensalzado por todos los hombres, sino que prefieren lo que justo a ellos, en cuanto a artistas, les parece bueno. De igual modo, raras veces son afortunados sus ataques cuando cultivan la sátira. Cervantes habría podido combatir la Inquisición, mas prefirió poner en ridículo a las víctimas de aquélla, es decir, a los herejes e idealistas de toda especie. Tras una vida llena de desventuras y contrariedades, todavía encontró gusto en lanzar un capital ataque literario contra una falsa dirección del gusto de los lectores españoles; combatió las novelas de caballería. Sin advertirlo, ese ataque se convirtió en sus manos en una ironización general de todas las aspiraciones superiores: hizo reír a España entera, incluidos todos los necios, y les hizo imaginar que ellos mismos eran sabios: es una realidad que ningún libro ha hecho reír tanto como el Don Quijote. Con semejante éxito, Cervantes, forma parte de la decadencia de la cultura española, es una desgracia nacional. Yo opino que Cervantes despreciaba a los hombres, sin excluirse a sí mismo; ¿o es que no hace otra cosa que divertirse cuando cuenta cómo se gastan bromas al enfermo en la corte del duque? Realmente, ¿no se habría reído incluso del hereje puesto sobre la hoguera? Más aún, ni siquiera le ahorra a su héroe aquel terrible cobrar conciencia de su estado al final de su vida: si no es crueldad, es frialdad, es dureza de corazón lo que le hizo escribir semejante escena final, es desprecio de los lectores, cuyas risas, como él sabía, no quedarían perturbadas por esta conclusión.

\section{Fragmentos del Canto XIII (Don Juan) ${ }^{41}$}

\section{Lord Byron (1788-1824)}

\section{8}

Pero ya ni amo ni odio en exceso, aunque un día no fue así. Si a veces me río es porque no puedo hacer nada mejor.

${ }^{40}$ Fragmento inédito (primavera-verano de 1877), recogido en nota del capítulo VI del Tratado Segundo de La genealogía de la moral (Buenos Aires: Ediciones Libertador, 2004).

${ }^{41}$ Fragmentos del Canto XIII de Don Juan (Madrid: Unidad Editorial, Colección Millenium, 1999). 
Aquí y allá lo reclaman mis rimas.

Bien satisfecho estaría de corregir

los males humanos y prevenir y no castigar

sus bajezas, si Cervantes no hubiera mostrado antes

en su lúcido relato el fracaso de tentativa tal.

9

De todas las narraciones es ésta la más triste

porque nos hace sonreír. Su héroe tiene razón

y siempre la razón persigue: reprimir el mal

es su único objeto y luchar con los imponderables

su galardón. Es su locura su virtud,

pero sus aventuras componen un panorama penoso

y más penosa aún es la excelsa moral que aprenden

de esta auténtica epopeya los que la han estudiado.

10

Corrigiendo los menoscabos y vengando la sinrazón, ayudando a las señoras y combatiendo a los malvados oponiendo su sola persona contra la fuerza de todos, libera del yugo impuesto a los nativos sin protección.

Ay, tan noble panorama como una vieja canción ¿ha de ser tema creativo por mero solaz de la imaginación, una broma o enigma, la fama tras prolongado esfuerzo? ¿y Sócrates mismo, Quijote sólo de la sabiduría?

11

Cervantes se rió de la pasada caballería española y esta única risa demolió el brazo armado de su país. Y rara vez España ha tenido héroes desde entonces. Mientras los romances [encandilaban, la gente se apartaba de sus vistosos atavíos $y$, no obstante, esos libros han causado tanto daño que toda su gloria como composición fue ganada venerablemente para perdición de este país. 
VIII. MUERTES Y DERROTAS: EL QUIJOTE Y EL HIDALGO

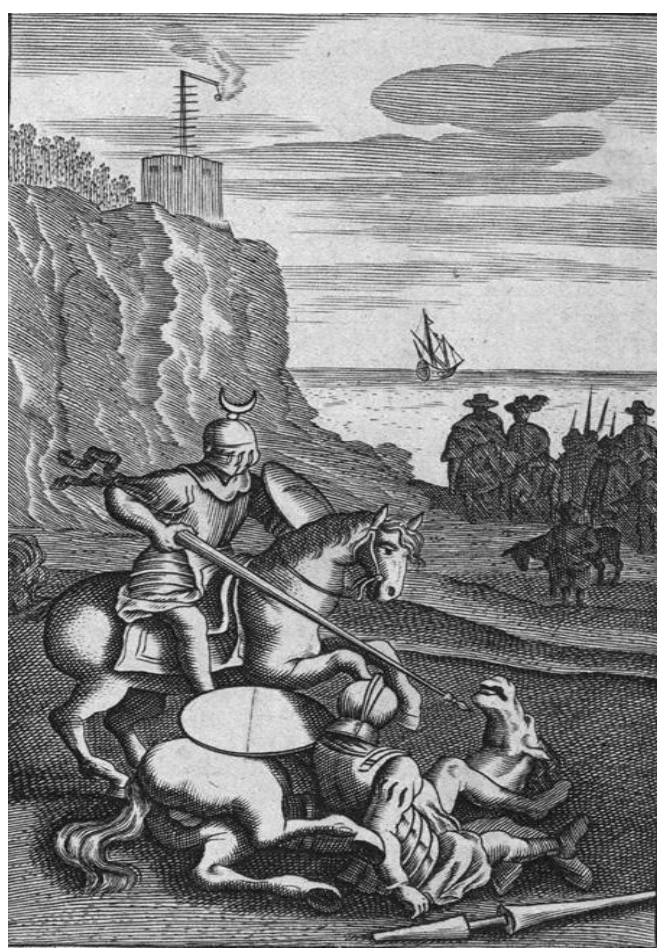

Bruselas, 1662

"-Señores caballeros, si aquí no hay otro remedio sino confesar o morir, y el señor don Quijote está en sus trece, y vuestra merced el de la Blanca Luna en sus catorce, a la mano de Dios, y dense.

Agradeció el de la Blanca Luna con corteses y discretas razones al visorrey la licencia que se les daba, y don Quijote hizo lo mesmo; el cual, encomendándose al cielo de todo corazón y a su Dulcinea - como tenía de costumbre al comenzar de las batallas que se le ofrecían-, tornó a tomar otro poco más del campo, porque vio que su contrario hacía lo mesmo, y sin tocar trompetas ni otro instrumento bélico que les diese señal de arremeter, volvieron entrambos a un mesmo punto las riendas a sus caballos; y como era más ligero el de la Blanca Luna, llegó a don 
Quijote a dos tercios andados de la carrera, y allí le encontró con tan poderosa fuerza, sin tocarle con la lanza (que la levantó, al parecer, de propósito), que dio con Rocinante y con don Quijote por el suelo una peligrosa caída. Fue luego sobre él, y poniéndole la lanza sobre la visera, le dijo.

- Vencido sois, caballero, y aun muerto, si no confesáis las condiciones de nuestro desafío.

Don Quijote, molido y aturdido, sin alzarse la visera, como si hablara dentro de una tumba, con voz debilitada y enferma, dijo:

-Dulcinea del Toboso es la más hermosa mujer del mundo, y yo el más desdichado caballero de la tierra, y no es bien que mi flaqueza defraude esta verdad. Aprieta, caballero, la lanza, y quítame la vida, pues me has quitado la honra."

(Segunda Parte, Cap. LXIV, p. 1047.)

La derrota de don Quijote con El Caballero de la Blanca Luna en las playas de Barcelona es seguramente una de las imágenes más tristes de toda la literatura. Hay quienes intentaron ver la ciudad como el lugar en que Cervantes había perdido su última ilusión de reconocimiento como soldado y por la Nación: viajar a América. Hay quienes se encargaron de rescatar que, incluso en el lenguaje, por la ausencia de arcaísmos tales como "fermosura", el ideal que ya agonizaba (por las asociaciones y degradaciones de la imagen de Dulcinea en constante asociación a un realidad baja y monetarizada) recibió la estocada final, quitándole a don Quijote la posibilidad de seguir sustentando este ideal en la acción caballeresca. Algunos pensaron en la luna y recordaron la fuente de Ariosto y de esa cordura que descansaba en Selene. Locura y cordura, ilusión y realidad. La derrota de don Quijote, la caída del ideal, el regreso y la espera de la muerte. La venganza de Sansón Carrasco, un sandio, otro burlista de un mundo barroco, un estudiante desocupado. ¿Muere verdaderamente don Quijote? Su derrota es algo verdaderamente peor, es una herida de huesos que siembra en el lector una angustia crónica hasta el final del libro, donde muere el otro, el hidalgo, Alonso.

Los textos transcritos refieren directa e indirectamente estas muertes, algunas de ellas (Darío, Fauquié y Mann) se pueden ver asociadas a las utopías sociales americanas y a las tensiones entre estas literaturas y las europeas. 


\section{Mi entrañable señor Cervantes ${ }^{42}$}

Jorge Luis Borges (1899-1986)

Y sin embargo, al final, cuando él vuelve, cuando vuelve a su pueblo natal para morir, sentimos lástima de él porque tenemos que creer en esa aventura. Él siempre había sido un hombre valiente. Fue un hombre valiente cuando le dijo estas palabras al caballero enmascarado que lo derribó: "Dulcinea del Toboso es la dama más bella del mundo, y yo el más miserable de los caballeros". Y sin embargo, al final, descubrió que toda su vida había sido una ilusión, una necedad, y murió de la manera más triste del mundo, sabiendo que había estado equivocado.

Ahora llegamos a lo que tal vez sea la escena más grande de ese gran libro: la verdadera muerte de Alonso Quijano. Tal vez sea una lástima que sepamos tan poco de Alonso Quijano. Sólo nos es mostrado en una o dos páginas antes de que se vuelva loco. Y sin embargo, tal vez no sea una lástima, porque sentimos que sus amigos lo abandonaron. $Y$ entonces también podemos amarlo. Y al final, cuando Alonso Quijano descubre que nunca ha sido Don Quijote, que Don Quijote es una mera ilusión, y que está por morirse, la tristeza nos arrasa, y también a Cervantes.

Cualquier otro escritor hubiera cedido a la tentación de escribir un "pasaje florido". Después de todo, debemos pensar que Don Quijote había acompañado a Cervantes muchos años. Y, cuando le llega el momento de morir, Cervantes debe haber sentido que se estaba despidiendo de un viejo y querido amigo. Y, si hubiera sido peor escritor, o tal vez si hubiera sentido menos pena por lo que estaba pasando, se hubiera lanzado a una "escritura florida".

Ahora estoy al borde de la blasfemia, pero creo que cuando Hamlet está por morir, creo que tendría que haber dicho algo mejor que "el resto es silencio". Porque eso me impresiona como escritura florida y bastante falsa. Amo a Shakespeare, lo amo tanto que puedo decir estas cosas de él y esperar que me perdone. Pero bien, también diré: Hamlet, "el resto es silencio"... no hay otro que pueda decir eso antes de morir. Después de todo, era un dandy y le encantaba lucirse.

Pero en el caso de Don Quijote, Cervantes se sintió tan sobrecogido por lo que estaba ocurriendo que escribió: "El cual entre suspiros y lágrimas de quienes lo rodeaban", y no recuerdo exactamente las palabras, pero el sentido es "dio el espíritu, quiero decir que se murió". Ahora bien, supongo que cuando Cervantes releyó esa oración debe haber sentido que no estaba

${ }^{42}$ Fragmento de "Mi entrañable señor Cervantes", tomado de Papel Literario de El Nacional, $1^{\circ}$ de agosto de 1999. 
a la altura de lo que se esperaba de él. Y sin embargo, también debe haber sentido que se había producido un gran milagro. De algún modo sentimos que Cervantes lo lamenta mucho, que Cervantes está tan triste como nosotros. Y por eso se le puede perdonar una oración imperfecta, una oración tentativa, una oración que en realidad no es imperfecta ni tentativa sino un resquicio a través del cual podemos ver lo que él sentía.

\section{D. $\mathbf{Q} .{ }^{43}$ \\ Rubén Dario (1867-1916)}

I.

Estamos de guarnición cerca de Santiago de Cuba. Había llovido esa noche; no obstante el calor era excesivo. Aguardábamos la llegada de una compañía de la nueva fuerza venida de España, para abandonar aquel paraje en que nos moríamos de hambre, sin luchar, llenos de desesperación y de ira. La compañía debía llegar esa misma noche según el aviso recibido. Como el calor arreciase y el sueño no quisiese darme reposo, salí a respirar fuera de la carpa. Pasada la lluvia, el cielo se había despejado un tanto y en el fondo oscuro brillaban algunas estrellas. Di suelta a la nube de tristes ideas que se aglomeraban en mi cerebro. Pensé en tantas cosas que estaban allá lejos; en la perra suerte que nos perseguía; en que quizá Dios podría dar un nuevo rumbo a su látigo y nosotros entrar en una nueva vía, en una rápida revancha. En tantas cosas pensaba...

¿Cuánto tiempo pasó? Las estrellas sé que poco a poco fueron palideciendo; un aire que refrescó el campo todo sopló del lado de la aurora y ésta inició su aparecimiento, entre tanto que una diana que no sé por qué llegaba a mis oídos como llena de tristeza, regó sus notas matinales. Poco tiempo después se anunció que la compañía se acercaba. En efecto, no tardó en llegar a nosotros. Y los saludos de nuestros camaradas y los nuestros se mezclaron fraternizando en el nuevo sol. Momentos después hablamos con los compañeros. Nos traían noticias de la patria. Sabían los estragos de las últimas batallas. Como nosotros estaban desolados, pero con el deseo quemante de luchar, de agitarse en una furia de venganza, de hacer todo el daño posible al enemigo. Todos éramos jóvenes y bizarros, menos uno; todos nos buscaban para comunicar con nosotros o para conversar, menos uno. Nos traían provisiones que fueron repartidas. A la hora del

${ }^{43}$ Fragmento del relato "D. Q.", tomado de Don Quijote no puede ni debe morir (Páginas cervantinas), prólogo de Jorge Eduardo Arellano (Academia Nicaragüense de la Lengua, 2002). 
rancho, todos nos pusimos a devorar nuestra escasa pitanza, menos uno. Tendría como cincuenta años, mas también podía haber tenido trescientos. Su mirada triste parecía penetrar hasta lo hondo de nuestras almas y decirnos cosas de siglos. Alguna vez se le dirigía la palabra, casi no contestaba; sonreía melancólicamente; se aislaba, buscaba la soledad; miraba hacia el fondo del horizonte, por el lado del mar. Era el abanderado. ¿Cómo se llamaba? No oí su nombre nunca.

II.

El capellán nos dijo dos días después:

- Creo que no nos darán la orden de partir todavía. La gente se desespera en deseos de pelear. Tenemos algunos enfermos. Por fin, ¿cuándo veríamos llenarse de gloria nuestra pobre y santa bandera? A propósito: ¿ha visto usted al abanderado? Se desvive por socorrer a los enfermos. Él no come; lleva lo suyo a los otros. He hablado con él. Es un hombre milagroso y extraño. Parece bravo y nobilísimo de corazón. Me ha hablado de sueños irrealizables. Cree que dentro de poco estaremos en Washington y que se izará nuestra bandera en el Capitolio, como lo dijo el obispo en su brindis. Le han apenado las últimas desgracias; pero confía en algo desconocido que nos ha de amparar; confía en Santiago, en la nobleza de nuestra raza, en la justicia de nuestra causa. ¿Sabe usted? Los otros seres le hacen burlas, se ríen de él. Dicen que debajo del uniforme usa una coraza vieja. El no les hace caso. Conversando conmigo, suspiraba profundamente, miraba el cielo y el mar. Es un buen hombre en el fondo; paisano mío, manchego. Cree en Dios y es religioso. También algo poeta. Dicen que por la noche rima redondillas, se las recita él solo, en voz baja. Tiene a su bandera un culto casi supersticioso. Se asegura que pasa las noches en vela; por lo menos, nadie le ha visto dormir. ¿Me confesará usted que el abanderado es un hombre original?

—Señor capellán — le dije_-, he observado ciertamente algo muy original en ese sujeto, que creo, por otra parte, haber visto no sé dónde. ¿Cómo se llama?

—No lo sé — contestóme el sacerdote_- No se me ha ocurrido ver su nombre en la lista. Pero en todas sus cosas hay marcadas dos letras: D. Q.

III.

A un paso del punto en donde acampábamos había un abismo. Más allá de la boca rocallosa, sólo se veía sombra. Una piedra arrojada rebotaba y no se sentía caer. Era un bello día. El sol caldeaba tropicalmente la atmós- 
fera. Habíamos recibido orden de alistarnos para marchar, y probablemente ese mismo día tendríamos el primer encuentro con las tropas yanquis. En todos los rostros, dorados por el fuego curioso de aquel cielo candente, brillaba el deseo de la sangre y de la victoria. Todo estaba listo para la partida, el clarín había trazado en el aire su signo de oro. Íbamos a caminar, cuando un oficial, a todo galope, apareció por un recodo. Llamó a nuestro jefe y habló con él misteriosamente. ¿Cómo os diré que fue aquello? ¿Jamás habéis sido aplastados por la cúpula de un templo que haya elevado vuestra esperanza? ¿Jamás habéis padecido viendo que asesinaban delante de vosotros a vuestra madre? Aquélla fue la más horrible desolación. Era la noticia. Estábamos perdidos, perdidos sin remedio. No lucharíamos más. Debíamos entregarnos como prisioneros, como vencidos. Cervera estaba en poder del yanqui. La escuadra se la había tragado el mar, la habían despedazado los cañones de Norteamérica. No quedaba ya nada de España en el mundo que ella descubriera. Debíamos dar al enemigo vencedor las armas, y todo; y el enemigo apareció, en la forma de un gran diablo rubio, de cabellos lacios, barba de chivo, oficial de los Estados Unidos, seguido de una escolta de cazadores de ojos azules. Y la horrible escena comenzó. Las espadas se entregaron; los fusiles también... Unos soldados juraban; otros palidecían, con los ojos húmedos de lágrimas, estallando de indignación y vergüenza. Y la bandera... cuando llegó el momento de la bandera, se vio una cosa que puso en todos el espanto glorioso de una inesperada maravi1la. Aquel hombre extraño, que miraba profundamente con una mirada de siglos, con su bandera amarilla y roja, dándonos una mirada de la más amarga despedida, sin que nadie se atreviese a tocarle, fuese paso a paso al abismo y se arrojó en él. Todavía de lo negro del precipicio devolvieron las rocas un ruido metálico, como el de una armadura.

IV.

El señor capellán cavilaba tiempo después:

- “D. Q.”... De pronto, creí aclarar el enigma. Aquella fisonomía, ciertamente, no me era desconocida.

-D. Q. —le dije — está retratado en este viejo libro. Escuchad: "Frisaba la edad de nuestro hidalgo con los cincuenta años; era de complexión recia, seco de carnes, enjuto de rostro, gran madrugador y amigo de la caza. Quieren decir que tenía el sobrenombre de Quijada o Quesada — que en esto hay alguna diferencia en los autores que de este caso escriben-, aunque por conjeturas verosímiles se deja entender que se llamaba Quijano." 


\title{
El Quijote entre la ortodoxia y la herejía ${ }^{44}$
}

\author{
Rafael Fauquié (1954)
}

La derrota de Don Quijote, el fin de sus sueños, su regreso a la cordura, plantean la fragilidad del ideal enfrentado a la realidad. En ese enfrentamiento podría leerse también la vulnerabilidad histórica del Imperio español. Su noción de grandeza, sus anhelos de universalismo se desplomaron ante una fragilidad económica que lo obligó a depender cada vez más estrechamente de naciones enemigas que se hicieron más y más fuertes a sus expensas. Conflicto análogo al de la brillante locura de Don Quijote opuesta a la inexorable cordura de los bachilleres y de los curas. Sueño y realidad: América era el sueño y España la realidad. ¿No trató, acaso, el propio Miguel de Cervantes de venir a América? En las decepciones de Don Quijote, en los fracasos de Cervantes, resuenan los ecos de aquellos Viajeros de Indias que buscaron El Dorado y concluyeron sus días consumidos por la violencia devoradora de las nuevas tierras. La individualidad victoriosa de unos pocos, se impuso por sobre la brutal inclemencia de un destino grabado a hierro y fuego. La fortuna era escasa y fueron pocos los elegidos. La literatura se encargaría de describir las peripecias de esos pocos.

\section{Vida de don Quijote y Sancho ${ }^{45}$}

Miguel de Unamuno (1864-1931)

Y si la bondad nos eterniza, ¿qué mayor cordura que morirse? "Verdaderamente se muere y verdaderamente está cuerdo Alonso Quijano el Bueno"; muere a la locura de la vida, despierta de su sueño.

Hizo Don Quijote su testamento y en él la mención de Sancho que éste merecía, pues si loco fue su amo parte a darle el gobierno de la ínsula, "pudiera estando cuerdo darle él de un reino, se le diera, porque la sencillez de su condición y fidelidad de su trato lo merece". Y volviéndose a Sancho, quiso quebrantarle la fe y persuadirle de que no había habido caballeros andantes en el mundo, a lo cual Sancho, henchido de fe y loco de remate cuando su amo se moría cuerdo, respondió llorando: “¡Ay, no se muera vuesa merced, señor mío, sino tome mi consejo y viva muchos años; porque

\footnotetext{
44 Tomado de La voz en el espejo (Caracas: Alfadil ediciones, 1993).

${ }^{45}$ Fragmento del capítulo 74 de Vida de don Quijote y Sancho, tomado de la edición de Alberto Navarro (Madrid: Cátedra, 2000).
} 
la mayor locura que pueda hacer un hombre en esta vida es dejarse morir sin más ni más!” ¿La mayor locura, Sancho?

$\mathrm{Y}$ consiento en mi morir con voluntad placentera clara y pura; que querer hombre vivir, cuando Dios quiere que muera, es locura,

pudo contestarte tu amo, con palabras del Maestre don Rodrigo Manrique, tales cuales en su boca las pone su hijo don Jorge, el de las coplas inmortales.

Y dicho lo de la locura de dejarse morir, volvió Sancho a las andadas, hablando a Don Quijote del desencanto de Dulcinea y de los libros de caballerías. ¡Oh, heroico Sancho, y cuán pocos advierten el que ganaste la cumbre de la locura cuando tu amo se despeñaba en el abismo de la sensatez y que sobre su lecho de muerte irradiaba tu fe, tu fe, Sancho, la fe de ti, que ni has muerto ni morirás! Don Quijote perdió su fe y murióse; tú la cobraste y vives; era preciso que él muriera en desengaño para que en engaño vivificante vivas tú.

\section{Travesía marítima con Don Quijote ${ }^{46}$}

Thomas Mann (1875-1955)

29 de mayo.

El tiempo ha continuado siendo bueno; ligeramente nublado y fresco. Desde que, a las cinco y media, nos hemos despedido de nuestros angostos lechos (en los que hemos pasado alguna noche de incesante vaivén), el barco ha vuelto a ponerse en movimiento, deslizándose pausado. Durante la noche ha estado quieto, así que por primera vez hemos podido dormir sin el golpeteo de las máquinas.

Hemos desayunado, hemos dado la última mano al equipaje y repartido las últimas propinas. Equipados para el arribo, hemos subido a cubierta para presenciar la llegada. Ya se levanta, en el vaho de la lejanía, una figura conocida, la estatua de la libertad, con su alta corona de laurel; un recuerdo

${ }^{46}$ Tomado de Travesía marítima con "Don Quijote" (Madrid: Ediciones Júcar, serie La Vela Latina, 1974). 
clasicista, un ingenuo símbolo, muy ajeno ya en medio de nuestro tiempo presente...

Me siento como en sueños; a causa de haber madrugado, por el particular contenido vital de esta hora. Además, también esta noche he soñado, en la ya acostumbrada paz sin ruidos, y trato de reconstruir el sueño, que provino de mi lectura de viaje. He soñado con Don Quijote; era él en persona, y yo hablaba con él. Lo mismo que la realidad, al presentársenos, se distingue, sin duda, de la representación que de ella nos habíamos hecho, Don Quijote tenía otro aspecto que el de las ilustraciones. Llevaba un bigote grueso y enmarañado, una frente alta y huida, y, bajo las cejas asimismo enmarañadas, unos ojos grises, casi ciegos. No se llamaba el Caballero de los Leones, sino Zaratustra. Teniéndolo ahora presente ante mí, era tan bondadoso y cortés, que yo, con indescriptible emoción, pensaba en las palabras leídas ayer: “...porque verdaderamente, como alguna vez se ha dicho, en tanto que Don Quijote fue Alonso Quijano el Bueno, a secas, y en tanto que fue Don Quijote de la Mancha, fue siempre de apacible condición y de agradable trato, y por esto no sólo era bien querido de los de su casa, sino de todos cuantos le conocían". Dolor, amor, compasión y admiración sin límites me llenaban por entero mientras se me hacía patente aquella caracterización; y todos esos sentimientos vibran en mí soñadoramente en esta hora de arribo.

Una tendencia, harto europea, de sentir y de pensar mirando hacia atrás... delante de nosotros, surgiendo de la niebla matinal, se van destacando lentamente los altos edificios de Manhattan, un fantástico paisaje colonial, una gigantesca ciudad torreada.

\section{Tristeza y placer de los sentidos ${ }^{47}$}

Friedrich Nietzsche (1844-1900)

¿Por qué la persona afligida está más inclinada a abandonarse ciegamente a los placeres de los sentidos? ¿Es el aturdimiento que producen lo que ella apetece? ¿O una necesidad de emoción a cualquier precio?

- Sancho Panza dice "Si los hombres sienten demasiado las tristezas, se vuelven bestias".

47 Tomado de los Fragmentos póstumos [1877], recogido en Aforismos [1877] (Ed. Edhasa, 1997). 


\title{
AUTORES Y OBRAS DE LA SELECCIÓN
}

\author{
I. IDENTIDAD: "Yo SÉ QUIÉN SOY" \\ "Clarín" (Leopoldo Alas): La fantasía de un delegado de Hacienda 475 \\ Joseph Conrad: "Un vagabundo feliz" .............................................. 476 \\ William Faulkner: Entrevista ............................................................. 477 \\ Iván Turgueniev: "Hamlet y Don Quijote: Dos visiones de la vida" . 478 \\ Giovanni Papini: "Don Quijote" ......................................................... 478
}

\section{EL AUTOR Y EL PERSONAJE}

Azorín (José Martínez Ruiz): La ruta de Don Quijote ........................ $\quad 480$

Carlos Cañeque: Quién ............................................................... 482

\section{REALIDAD Y FICCIÓN: LA CONTINUA MUDANZA}

Mario Vargas Llosa: Cartas a un joven novelista ............................. 485

Vladimir Nabokov: Curso sobre el Quijote ...................................... 486

Franz Kafka: "La verdad sobre Sancho Panza" .................................. 487

David Hume: Sobre la sencillez y el refinamiento en el arte de escribir 487

Michael Foucault: Las palabras y las cosas ..................................... $\quad 488$

Jorge Luis Borges: "Mi entrañable señor Cervantes" ........................ 491

\section{IMITACIÓN Y LOCURAS}

Guillaume Apollinaire: El poeta asesinado ....................................... 495

Henry Fielding: La historia de Tom Jones ........................................ 495

Lawrence Sterne: Vida y opiniones del caballero Tristram Shandy. 496

Mark Twain: Las aventuras de Huckleberry Finn ........................... 496

Graham Greene: Monseñor Quijote .................................................. 497

Washington Irving: "El viaje" ......................................................... 498

Feodor Dostoievski: Diario de un escritor ...................................... 499

Albert Camus: El mito de Sisifo ...................................................... 501

Camilo José Cela: “¡Ah!, la ordenación social” .................................... 501

G. W. F. Hegel: Lecciones sobre la estética ...................................... 502

W. H. Auden: "Balaam y su asna" ................................................. 503

Carlos Drumond de Andrade: Don Quixote ...................................... 504 


\section{DulCinea: El IDEAL Y LA IMAGINACIÓN}

Octavio Paz: "La Dulcinea de Marcel Duchamp" ............................ 509

Thomas Love Peacock: La abadía de las pesadillas ...................... 509

Juan José Arreola: "Teoría de Dulcinea" ....................................... 510

Marco Denevi: "Dulcinea del Toboso"......................................... 510

Jorge Luis Borges: "Sueña Alonso Quijano”.................................. 511

\section{ESPAÑA: LA RAZA Y EL DESTINO}

Émile M. Cioran: La tentación de existir ........................................... $\quad 515$

Milan Kundera: El arte de la novela .............................................. 516

José Carlos Mariátegui: "Elogio a Cervantes" ................................. 516

Antonio Machado: “Las meditaciones del Quijote de José Ortega y

Gasset"

\section{LeCTORES: CoRRECTORES Y LEGISLADORES}

Jorge Luis Borges: "Pierre Menard, autor del Quijote" ................... 521

Carlos Fuentes: Cervantes o la crítica de la lectura ........................ $\quad 522$

Ernest Hemingway: "Cómo condensar a los clásicos" .................... 523

Friedrich Nietzsche: La genealogía de la moral ............................ $\quad 524$

Lord Byron: Don Juan ................................................................. 524

\section{Muertes y derRotas: El QuiJote y el Hidalgo}

Jorge Luis Borges: "Mi entrañable señor Cervantes" ...................... 528

Rubén Darío: "D. Q.” ...................................................................... 529

Rafael Fauquié: La voz en el espejo ............................................. 532

Miguel de Unamuno: Vida de don Quijote y Sancho ....................... 532

Thomas Mann: Travesía marítima con Don Quijote ........................ 533

Friedrich Nietzsche: "Tristeza y placer de los sentidos" ................. 534 


\section{BIBLIOGRAFÍA}

Alas, Leopoldo ("Clarín"): La fantasía de un delegado de Hacienda, Oviedo, España: Ed. Nobel, 1999.

Allen, John Jay: Don Quixote, Hero or Fool? A Study in Narrative Technique. University of Florida Press, 1969.

Apollinaire, Guillaume: El poeta asesinado. Barcelona: Macondo Ediciones, Editorial Lumen, 1969.

Arreola, Juan José: "Teoría de Dulcinea". En Confabulario total. México: Fondo de Cultura Económica, tercera edición, 1962.

Auden, W. H.: "Balaam y su asno". En W. H. Auden, La mano del teñidor. Ensayos sobre cultura, poesía, teatro, música y ópera. Adriana Hidalgo, editora. Buenos Aires, 1999.

Borges, Jorge Luis: "Sueña Alonso Quijano", del poemario La rosa profunda. En Obra poética, 3. Madrid: Editorial Alianza, 1998.

Borges, Jorge Luis: "Pierre Menard, autor del Quijote". En Jorge Luis Borges, Ficciones. Madrid: Alianza Editorial, 1997.

Borges, Jorge Luis: "Mi entrañable señor Cervantes". En Papel literario de El Nacional, $1^{\circ}$ de agosto de 1999.

Camus, Albert: El mito de Sísifo. Madrid: Alianza Editorial, 1999.

Cañeque, Carlos: Quién. Editorial Destino, 1997.

Casalduero, Joaquín: Sentido y forma del Quijote. Madrid: Ediciones Ínsula, 1949.

Cela, Camilo José: “¡Ah, la ordenación social!”. En Camilo José Cela, Las compañias convenientes y otros fingimientos y cegueras. Barcelona: Ediciones Destino, 1981.

Cioran, Émile. M.: "Pequeña teoría del destino". En Émile Cioran, La tentación de existir. Madrid: Taurus, 2000.

Conrad, Joseph: "Un vagabundo feliz" [1910]. En Joseph Conrad, Notas de vida y letras. Madrid: Ediciones B, 1988.

Darío, Rubén: "D. Q.". En Don Quijote no puede ni debe morir (Páginas cervantinas), prólogo de Jorge Eduardo Arellano. Academia Nicaragüense de la Lengua, 2002.

Denevi, Marco: "Dulcinea del Toboso". En Marco Deveni, Obras Completas. Buenos Aires, Ediciones Corregidor, 1980.

Dostoievski, Fiódor Mijáilovich: "La mentira se salva por otra mentira". En F. M. Dostovievski, Diario de un escritor. Madrid: Editorial Espasa Calpe, 1960.

Drummond de Andrade, Carlos: "IX. Disquisición en el insomnio". Don Qixote. Traducción de Edmundo Font. México: Secretaría de Educación Pública, Dirección General de Publicaciones y Medios, 1985.

Durán, Manuel: La ambigüedad en el Quijote. Xalapa, México: Universidad Veracruzana, 1961

Faulkner, William: "Entrevista a Faulkner". En Ana Ayuso (antologadora), El oficio de escritor. Entrevistas. México: Biblioteca ERA, 1986.

Fauquié, Rafael: La voz en el espejo. Caracas: Alfadil ediciones, 1993.

Fielding, Henry: The History of Tom Jones, A Foundling. Fredson Bowers (ed.), Wesleyan Edition of the Works of Henry Fielding, 2 vols. Oxford: Oxford University Press, 1975. 
Foucault, Michel: Las palabras y las cosas. Traducción de Elsa Cecilia Frost. México: siglo Veintiuno Editores, 1999.

Fuentes, Carlos: Cervantes o la crítica de la lectura. Alcalá de Henares: Centro de Estudios Cervantinos, 1994.

Greene, Graham: Monseñor Quijote. Madrid: Editorial Gredos, 1958.

Hegel, Georg Wilhem Friedrich: Lecciones sobre la estética. Madrid: Mestas Ediciones, 2003.

Hemingway, Ernest: "Cómo condensar a los clásicos". Artículo publicado en The Toronto Star Weekly, el 20 de agosto de 1921.

Hume, David: Sobre la sencillez y el refinamiento en el arte de escribir. Madrid: Alianza Editorial, 1983.

Irving, Washington: "El viaje". En Washington Irving, Cuentos de la Alhambra. Buenos Aires: Acme, 1975.

Kafka, Franz: "La verdad sobre Sancho Panza". En Franz Kafka, La muralla china: cuentos, relatos y otros escritos. Madrid: Alianza Editorial, 1973.

Kundera, Milan: El arte de la novela. Madrid: Editorial Alfaguara, 1986.

Lord Byron: Don Juan. Madrid: Unidad Editorial, Colección Millenium, 1999.

Machado, Antonio: "Las meditaciones del Quijote de José Ortega y Gasset". En Prosas dispersas, edición anotada de Jordi Doménech. Madrid: Editorial Páginas de Espuma, 2001.

Malraux, André: El hombre precario y la literatura. Buenos Aires: Sur, 1977.

Mann, Thomas: Travesía marítima con "Don Quijote". Madrid: Ediciones Júcar, 1974.

Mariátegui, José Carlos: "Elogio a Cervantes". En José Carlos Mariátegui, Escritos juveniles, la edad de piedra. Tomo I. Lima: Empresa editora Amauta, 1987.

Martínez Ruiz (“Azorín”), José: "Los Sanchos de Criptana”. En "Azorín”, La ruta de Don Quijote. Madrid: Ediciones Cátedra, 1999.

Nabokov, Vladimir: Curso sobre el Quijote. Madrid: Ediciones B, 2004.

Nietzsche, Friedrich: Aforismos. Edhasa, 1997.

Nietzsche, Friedrich: La genealogía de la moral. Buenos Aires: Ediciones Libertador, 2004.

Ortega y Gasset, José: Meditaciones del Quijote [1914]. Julián Marías, editor. Madrid: Ed. Cátedra, 2001.

Sterne, Laurence: Vida y opiniones del caballero Tristram Shandy. Ed. Cátedra, 1990.

Papini, Giovanni: "Don Chisciotte". En Giovanni Papini, Testimonios. Milan: Facchi, 1918.

Paz, Octavio: "La Dulcinea de Marcel Duchamp". Árbol adentro. Barcelona: Edit. SeixBarral, 1987.

Peacock, Thomas L.: La abadia de las pesadillas. www.ucm.es/info/quijote/q-peacoc.htm Riley, Edward C.: Cervantes's Theory of the Novel. Oxford: Clarendon Press, 1962.

Turgueniev, Iván S.: "Hamlet y don Quijote: Dos visiones de la vida". En Ivan S. Turquéniev, Páginas autobiográficas. Barcelona: Alba Editorial, 2000.

Twain, Mark: Las aventuras de Huckleberry Finn. Madrid: Editorial Dintel, 1982.

Unamuno, Miguel de: Vida de don Quijote y Sancho. Madrid: Cátedra, 2000.

Vargas Llosa, Mario: Cartas a un joven novelista. Barcelona: Planeta, 1997. 